\title{
THE NEXT GENERATION OF RENEWABLE ELECTRICITY POLICY HOW RAPID CHANGE IS BREAKING DOWN CONVENTIONAL POLICY CATEGORIES
}

Toby D. Couture, E3 Analytics

David Jacobs, IET - International Energy Transition

Wilson Rickerson, Meister Consultants Group

Victoria Healey, National Renewable Energy Laboratory (NREL) 


\section{Table of Contents}

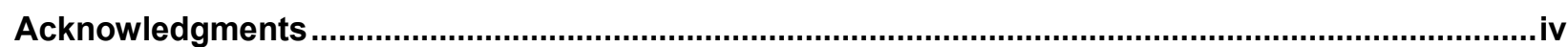

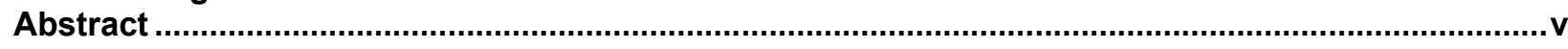

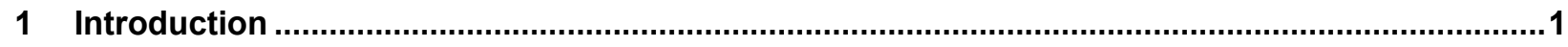

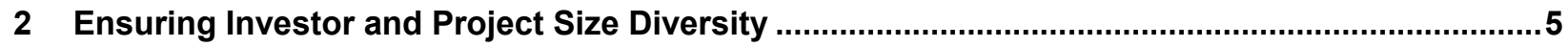

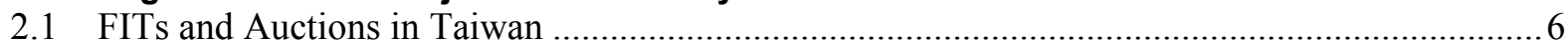

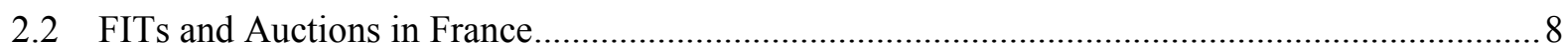

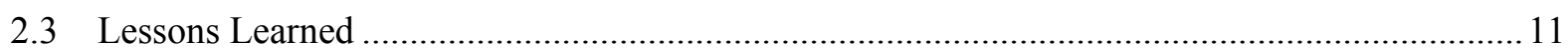

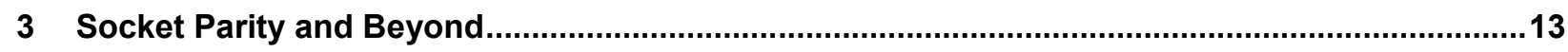

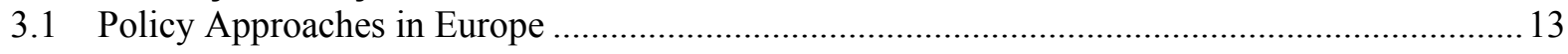

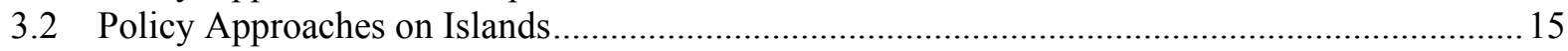

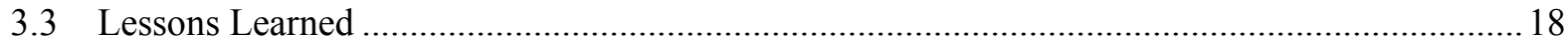

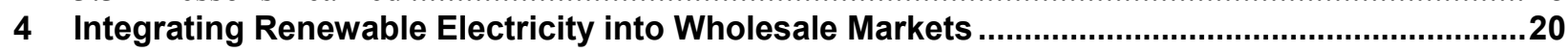

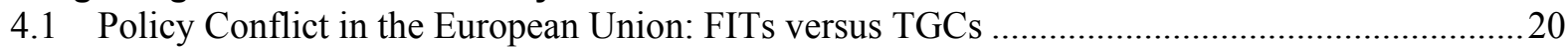

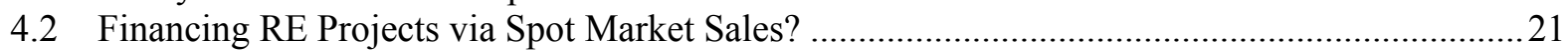

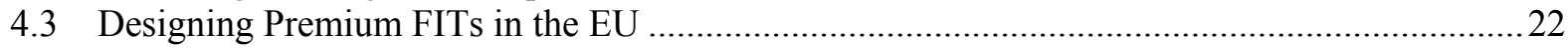

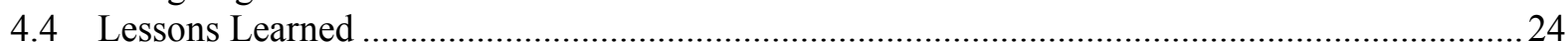

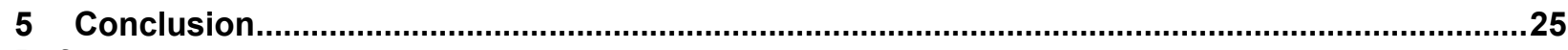

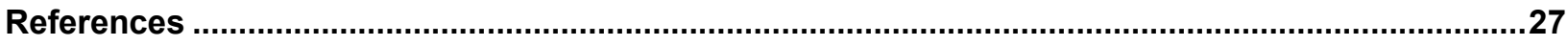

\section{List of Figures}

Figure 1. Distribution of PV project sizes in Taiwan (2011 - Q2:2014) ..............................................7

Figure 2. Breakdown of installed solar PV capacity in mainland France from 2011 to 2014 (MW) .............9

Figure 3. Breakdown of installed solar PV capacity in mainland France by project size (\%) (Sept 30, 2014)

Figure 4. Development of FIT payment levels and retail electricity rates in Germany ...................................14

Figure 5. Share of fixed versus variable costs of selected power generation technologies .....................22

Figure 6. Functioning of planned contracts for differences in the UK .................................................2

\section{List of Tables}

Table 1. Traditional Renewable Electricity Policy Categories .................................................................

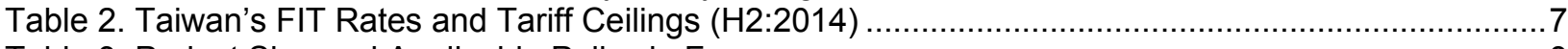

Table 3. Project Size and Applicable Policy in France .................................................................... 8

Table 4. Purchase Prices under FITs and Tendering in France (Q3:2013) ....................................10

Table 5. Summary of On-site Generation Policies in the Cayman Islands, Grenada, and the Seychelles. 16 


\section{List of Abbreviations and Acronyms}

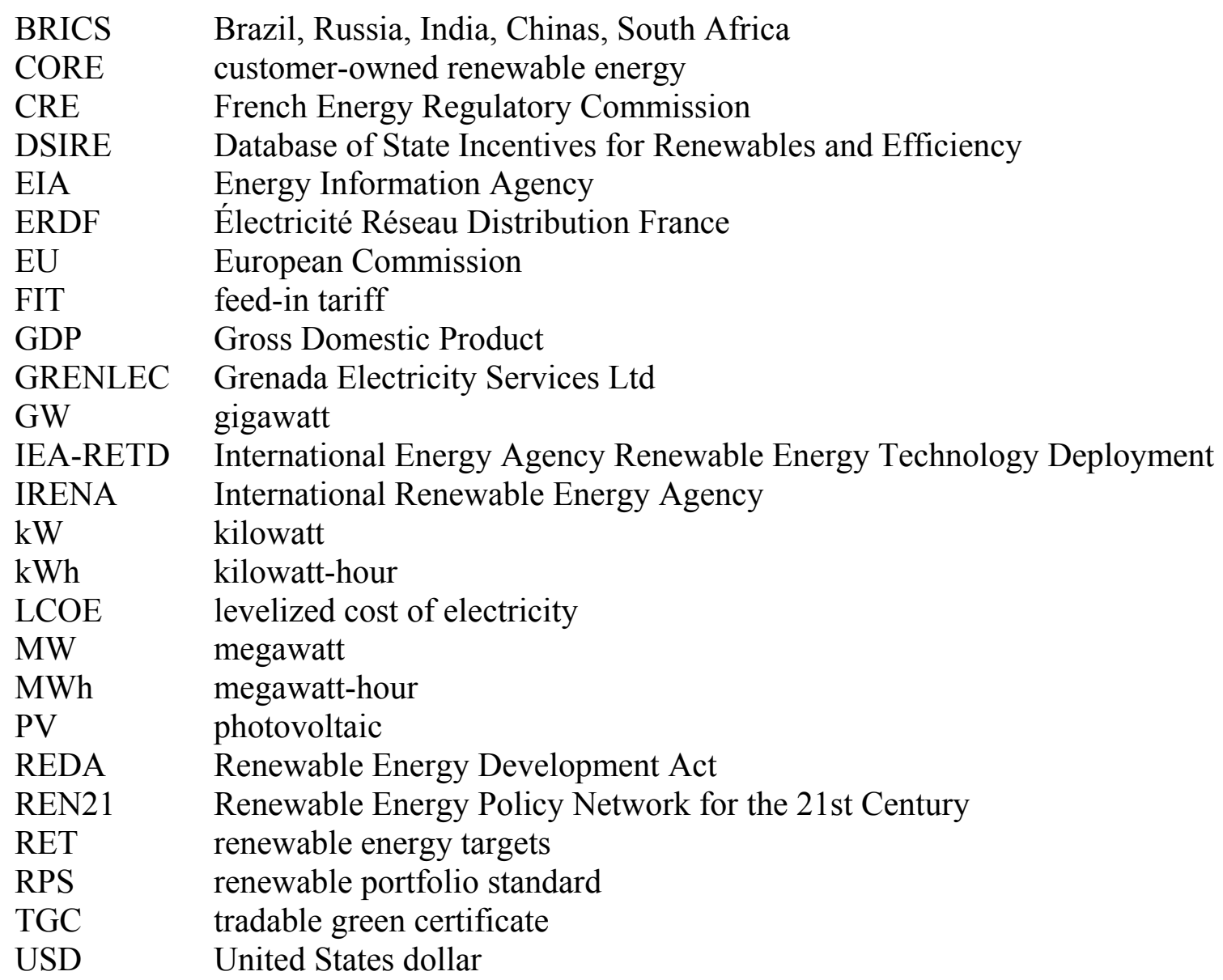




\section{Acknowledgments}

This report was prepared for the Clean Energy Solutions Center (Solutions Center). The Solutions Center is an initiative of the Clean Energy Ministerial (CEM), a global forum to share best practices and promote policies and programs that encourage and facilitate the transition to a global clean energy economy. As the operating agency of the Solutions Center, the National Renewable Energy Laboratory (NREL) is responsible for publications of the Solutions Center. The authors acknowledge Dr. Ian Lloyd of the United States Department of Energy; Ron Benioff, Terri Walters, and Dr. Jaquelin Cochran of the National Renewable Energy Laboratory; and William Becker of the Center for the New Energy Economy for their reviews. 


\section{Abstract}

A number of policies have been used historically in order to stimulate the growth of the renewable electricity sector. This paper examines four of these policy instruments:

competitive tendering (sometimes called renewable electricity auctions), feed-in tariffs, net metering and net billing, and tradable renewable energy certificates. ${ }^{1}$ In recent years, however, a number of changes to both market circumstances and to policy priorities have resulted in numerous policy innovations, including the emergence of policy hybrids. With no common language for these evolving policy mechanisms, policymakers have generally continued to use the same traditional policy labels, occasionally generating confusion as many of these new policies no longer look, or act, like their traditional predecessors. In reviewing these changes, this paper makes two separate but related claims: first, policy labels themselves are breaking down and evolving. As a result, policy comparisons that rely on the conventional labels may no longer be appropriate, or advisable. Second, as policymakers continue to adapt, we are in effect witnessing the emergence of the next generation of renewable electricity policies, a change that could have significant impacts on investment, as well as on market growth in both developed and developing countries.

\footnotetext{
${ }^{1}$ A number of additional policies have been used in order to stimulate the growth of the renewable energy sector, including incentives, rebates and the streamlining of administrative and grid connection procedures. However, this paper focuses on these four policy instruments, as it is here where the changes in definitions are most notable.
} 


\section{Introduction}

Renewable sources of electricity have grown significantly within the global power sector during the past decade. Total installed renewable electricity capacity increased from 800 Gigawatts $(\mathrm{GW})$ in 2004 to $1,560 \mathrm{GW}$ by the end of 2013, and renewable energy sources now supply $22.1 \%$ of global electricity demand of which $5.8 \%$ is from sources other than large hydro (REN21 2014).

Renewable energy market growth has been driven by a combination of factors, including government policy, rising energy prices, and rapidly declining renewable energy costs. By 2013, 144 countries around the world had adopted specific targets for renewable energy development, up from only 48 countries in 2004. The growth in renewable energy targets (RETs) has been accompanied by a far-reaching international debate as to which mechanism(s) should be used to help achieve these targets. In the United States, many statelevel renewables portfolio standard (RPS) policies are due to expire in the years ahead, a fact that is likely to spur further debate about the best policy pathways forward.

While the majority of renewable energy market growth to date has occurred in Europe and North America, a greater share of renewable electricity investment is moving toward developing countries (REN21 2014):

- China now leads the world in terms of installed renewable electricity capacity, and the BRICS nations (Brazil, Russia, India, China, and South Africa) collectively account for $29 \%$ of global non-hydropower renewable electricity capacity.

- Approximately $43 \%$ of global renewable electricity investment (i.e., USD $\$ 93$ billion) occurred in developing countries in 2013.

- Top countries in terms of new renewable electricity investment relative to annual gross domestic product (GDP) in 2013 included Uruguay, Mauritius, Costa Rica, South Africa, and Nicaragua.

As developing countries craft renewable electricity policies, they should consider whether traditional policies make sense in their own market or whether new policy innovations may better meet their needs or better respond to their policy priorities.

\section{Policy Best Practices?}

Europe and North America have had vigorous debates about the comparative merits of specific policies, and many experts elsewhere in the world have looked to these debates for policy guidance. In the United States in the 1990s, for example, policymakers puzzled over whether to adopt RPSs (i.e., mandatory targets for renewable electricity) or public benefits funds (i.e., surcharges on electricity bills used to support grants, rebates, and other incentives) (Wiser et al. 1996). In the 1990s and 2000s in Europe, policymakers debated whether to use feed-in tariffs (FITs) or tradable credits (Butler \& Neuhoff 2008) or whether to move to auction mechanisms instead. In the United States, there are now several ongoing debates between net metering and FIT regimes (Trabish 2014), as well as about how to combine elements of different policies in new ways (Krasko and Doris 2012, Kreycik et al. 2011).

Although these best practice debates have been well documented, policy definitions are increasingly fluid, the competitive environment is continually evolving, and policymakers are increasingly required to innovate in order to reconcile different policy objectives. As a result, "best practice" may be less about adopting policy 'A' or policy 'B', but rather about combining a wide range of policy design elements into a flexible and well-adapted policy 
framework. In some cases, this may involve abandoning the traditional policy categories altogether, and pushing out in new directions.

\section{Policy Definitions Are Increasingly Fluid}

Table 1 summarizes a number of widely used renewable electricity policies and provides simplified traditional definitions. The table focuses specifically on how the remuneration that power producers receive is determined and structured. ${ }^{2}$

Table 1. Traditional Renewable Electricity Policy Categories

\begin{tabular}{lll}
\hline Policy Instrument & $\begin{array}{l}\text { How Prices Are Typically } \\
\text { Determined }\end{array}$ & How Compensation Is Typically Structured \\
\hline $\begin{array}{l}\text { Tendering or } \\
\text { Reverse Auctions }\end{array}$ & $\begin{array}{l}\text { Competition among } \\
\text { generators }\end{array}$ & Long-term fixed price contracts \\
\hline Feed-in Tariffs & Set administratively & Long-term fixed price contracts \\
\hline Net Metering & $\begin{array}{l}\text { Pegged to the retail } \\
\text { electricity rate }\end{array}$ & $\begin{array}{l}\text { System output offsets retail electricity purchases } \\
\text { Excess generation can be applied as a credit to } \\
\text { future electricity purchases }\end{array}$ \\
\hline Tradable & $\begin{array}{l}\text { Short-term fluctuations in } \\
\text { credit and spot market } \\
\text { prices }\end{array}$ & $\begin{array}{l}\text { Variable pricing, depending on supply and } \\
\text { demand conditions, and ability of generators to } \\
\text { secure short-term contracts }\end{array}$ \\
\hline
\end{tabular}

It is important to note that the "traditional" policy toolkit described above in Table 1 was largely developed when the cost of renewable energy technologies was significantly higher than both conventional electricity prices and utilities' avoided generation costs. As renewable technology costs continue to fall and conventional fuel prices continue to rise, these policies are being adapted to these new power sector economics. In Germany, for example, the levelized cost of solar energy is now significantly below the retail price of electricity (Ferroukhi et al. 2014). In other regions such as in the Caribbean and the Pacific Islands, renewable electricity sources are increasingly competitive at the wholesale level as well, undercutting the avoided cost of generation from diesel or heavy fuel oil (Rickerson et al. 2012). Partly in response to these changing cost dynamics, policymakers in certain jurisdictions are beginning to introduce policies that do not fit neatly into the "traditional" policy categories.

The conversation has been further complicated by the fact that the traditional policy labels are no longer applied in a standard or uniform manner. As renewable energy policies have spread internationally during the past decade, the labels have been applied and interpreted in a wide variety of different ways. For example:

- In the United States in 2009 and 2010, for example, California was debating whether to adopt a FIT or an auction, while in the neighboring state of Nevada some commentators were arguing that auctions were in fact a type of FIT (Carmichael 2010, Nimmons 2009).

- In Australia, many states used the term "feed-in tariffs" to refer to policies that paid a fixed tariff only for excess generation (e.g., Tasmanian Government 2013) in contrast to traditional FITs, which compensate producers for their full output. These Australian

\footnotetext{
${ }^{2}$ Note that each involves a wide range of other design considerations beyond remuneration structure. See: Barnes et al. 2013, Couture et al. 2010, Maurer \& Barroso 2011, Rader \& Hempling 2001, Rickerson et al. 2012.
} 
policies are arguably closer in design to traditional net metering policies than to European FITs.

- Grenada's "Renewable Standard Offer" policy (which is also referred to as "net billing") more closely resembles a traditional FIT because all of the generated power is purchased under a long-term agreement, and none of it can be used to offset on-site load (GRENLEC 2011).

- In Kenya, the national FIT law establishes a price ceiling under which contracts must be negotiated on a case-by-case basis (Ministry of Energy 2010). Kenya's FIT represents a departure from European FITs, under which a minimum price is typically guaranteed on a standard offer basis.

As these examples and many other examples illustrate, the same policy labels are frequently used to mean different things. These inconsistent definitions can make it difficult for policymakers to compare the experiences of one jurisdiction with those of another. For instance, it may be challenging to compare the impact of FITs in Australia to the impact of FITs in Germany because the two policies are designed quite differently. In some cases, different policies sharing one common label differ from one another so fundamentally that using the same labels is no longer appropriate, or advisable. Instead, this paper argues that policymakers should focus on the underlying policy design elements, rather than comparing policies using the traditional labels. A focus on policy structure is also helpful as it can help highlight new ways in which policymakers can combine the various elements of different policies together to better meet their objectives.

\section{The "Next Generation" of Renewable Electricity Policy}

There have been a number of recent studies that attempt to characterize what the "next generation" of renewable electricity policy will look like (Miller et al. 2013; Kreycik et al. 2011). This paper seeks to build on this literature by exploring specific examples of recent policy innovation. ${ }^{3}$

The following three sections of the paper focus on three emerging policy trends, including the:

- Desire to support a diversity of investors and project sizes

- Need to design new policy approaches to deal with markets that have reached (or surpassed) socket parity ${ }^{4}$

- Push to integrate non-hydro renewable electricity technologies into wholesale spot markets.

\footnotetext{
${ }^{3}$ The focus here is specifically on renewable electricity policies, but the authors acknowledge that the future of policymaking will require approaches that take into account issues such as grid integration, electricity market reform, and the ongoing evolution of utility business models.

${ }^{4}$ Socket parity is defined as the point at which the cost of generation from on-site renewable energy systems is lower than the cost to purchase retail electricity from the grid, including taxes and fixed charges.
} 
It is in response to these and other related trends that the distinctions between the traditional policy categories are beginning to break down. The following sections examine each of these three trends in greater detail. Section 2 takes a closer look at efforts to combine FITs and auctions together in Taiwan and France in order to improve cost-efficiency, while maintaining access to a wider range of market participants than typically possible under auctions alone. Section 3 examines how policymakers in both Europe and in a number of island regions around the world are attempting to regulate the development of distributed RETs in markets beyond socket parity. And, Section 4 analyzes efforts in Germany to integrate variable renewable electricity technologies into wholesale spot markets as the share of renewable electricity in the market grows. 


\section{Ensuring Investor and Project Size Diversity}

In recent years, policymakers have been attempting to strike the right balance between a number of different, and some would argue competing, policy priorities.

On one hand, policymakers have been seeking (or have been required by statute) to obtain the lowest possible price for electricity from renewable electricity projects. This is reflected in the design of many RPS policies in both the U.S. and Canada and in the growing interest in competitive tendering (e.g., reverse auctions) globally (Cozzi 2012). The number of developing countries that utilize auction mechanisms has increased significantly during the past several years. Auctions have the advantage of encouraging price competition. However, they also "tend to favour large players that are able to afford the associated administrative and transaction costs (Lucas et al. 2013)" and may only favor certain types of renewables over others (e.g., large wind plants will likely beat out small biogas projects if the two compete against one another). ${ }^{5}$

On the other hand, policymakers have realized that focusing on price alone can leave other priorities or values insufficiently reflected. One such priority is the desire to encourage a wider diversity of investors to participate in renewable energy investment, including citizens, farmers, communities, small businesses and local governments.

In order to balance the objective of price competition with the objective of investor diversity, policymakers have attempted to combine policies in a range of different ways, including using policies such as auctions and FITs in parallel to encourage projects of different sizes. ${ }^{6}$ Under this approach, auctions are typically used to procure larger systems (e.g., $>1 \mathrm{MW}$ ) while FITs are used to procure smaller projects (e.g., $<100 \mathrm{~kW}$ ). The aim in both of the cases examined here is to encourage investor diversity by keeping the barriers to entry low for certain kinds of market participants, while at the same time encouraging competition among larger project developers to secure lower prices for consumers.

Taiwan and France have been selected for a few key reasons: France was one of the first countries in the world to combine the use of both FITs and auctions for different project sizes starting in 2001, using FITs for all projects under $12 \mathrm{MW}$ and a form of tendering for all projects above $12 \mathrm{MW}$. Taiwan followed suit in 2011, combining FITs and auctions together in a slightly different way, and remains one of the leading examples of the two being used together outside of Europe. Moreover, both Taiwan and France have used the policies to achieve similar objectives, including encouraging a wider diversity of investors, and reducing the barriers to entry for certain project sizes. As such, both countries provide valuable insights into the various ways in which these policies have been combined in recent years, and demonstrate clearly that the two can be combined to achieve specific objectives. ${ }^{7}$

\footnotetext{
${ }^{5}$ One example of attempting to encourage technological diversity can be seen in Brazil, where efforts have been made to increase technological diversity by holding technology-specific auctions. A number of European researchers have suggested that encouraging a broad mix of RE technologies, while potentially costlier in the short-term, remains the least-cost option in the long-term to achieve more ambitious RE targets, primarily as it allows a number of technologies to come down the cost curve simultaneously (Huber et al. 2004). This view, once quite controversial, has arguably been vindicated by the recent declines in solar PV costs, which are now broadly competitive with wind power in certain markets.

${ }^{6}$ Another approach to encourage project size diversity can be found in certain RPS, where technology specific targets, or carve-outs, have been introduced (Hurlbut 2008).

${ }^{7}$ Other approaches designed to encourage investor diversity include streamlined grid interconnection procedures for smaller projects, and targeted funds or grants for energy entrepreneurs.
} 


\subsection{FITs and Auctions in Taiwan}

In 2009, the Taiwanese government enacted a national Renewable Energy Development Act (REDA). At the time, Taiwan anticipated achieving a target of $75 \mathrm{MW}$ of new solar photovoltaic (PV) projects. Since then, however, Taiwan had significantly expanded its PV target to procure a total of $6.2 \mathrm{GW}$ of solar PV by $2030 .{ }^{8}$ Due primarily to constraints over access to land, Taiwan had chosen to place a higher priority on rooftop solar PV systems. By the end of 2014, Taiwan is likely to have a total installed solar PV capacity of over $600 \mathrm{MW}{ }^{9}$

In order to achieve its target, Taiwan is using both a FIT policy and a competitive tendering scheme. ${ }^{10}$ Under the competitive tendering scheme, bidders must submit their project proposals with their bid price. Winning bidders are then allowed to sell electricity to TaiPower at the same rate for twenty years under fixed price contracts (Ming-Zhi Gao 2014). However, Taiwan allows certain project categories to be formally exempted from the tendering process, offering a twenty-year FIT contract instead. FITs are currently offered, at different tariffs, in the following cases: ${ }^{11} 1$ ) projects between $1 \mathrm{~kW}$ and $10 \mathrm{~kW}$ that are owned by individual residents; 2) projects smaller than $30 \mathrm{~kW}$; 3 ) projects up to $5 \mathrm{MW}$ in size that are owned directly by local governments, or by state-owned enterprises, and 4) projects on government buildings that are rented to private owners and receive formal approval from local governments (Ming-Zhi Gao 2014). ${ }^{12}$ This means that PV projects of less than $30 \mathrm{~kW}$ in Taiwan can technically apply to participate in the tendering scheme, or apply to participate in the FIT, provided they qualify. More flexibility is also given to particular project types, such as those owned by local governments. This increases investor choice, while lowering the barriers to entry for certain project types.

It is important to note that in Taiwan the administratively set rates offered under the FIT policy act as "tariff ceilings." In order words, bid prices under its tendering policy are implicitly capped: bids higher than the current FIT rates will not be accepted. This means that the projects that qualify for exemptions from the tendering scheme are effectively given preferential treatment: they benefit from higher tariff values, and a less burdensome administrative process to obtain a contract. They also face a lower risk that their project proposal will fail to result in a contract to build. In this way, Taiwan has attempted to make it both easier, and more attractive, for certain project types, most notably small projects under $30 \mathrm{~kW}$ and those owned by local governments, to participate.

\footnotetext{
${ }^{8}$ See: http://web3.moeaboe.gov.tw/ECW/english/news/News.aspx?kind=6\&menu id=958\&news id=3769

${ }^{9}$ Ibid.

${ }^{10}$ Projects can also be supported directly via grants or cash incentives by local or national governments.

${ }^{11}$ Note that the number and scope of the exemptions have been growing since the combined policy was introduced in March 2011.

${ }^{12}$ Ming-Zhi Gao 2014b. See also http://web3.moeaboe.gov.tw/ECW/english/news/

News.aspx?kind $=6 \&$ menu id $=958 \&$ news id $=3769$
} 
Table 2 provides a snapshot of the tariff ceilings offered as part of Taiwan's FIT policy in 2014.

Table 2. Taiwan's FIT Rates and Tariff Ceilings (H2:2014)

\begin{tabular}{ll}
\hline System Capacity & H2:2014 Tariff Rates \\
\hline$\geq \mathbf{1}-<\mathbf{1 0} \mathbf{~ k W}$ & USD \$235.0/MWh \\
$\mathbf{2 1 0}-<\mathbf{1 0 0} \mathbf{~ k W}$ & USD \$210.7/MWh \\
$\mathbf{2 1 0 0 - < 5 0 0 ~ k W}$ & USD \$198.4/MWh \\
$\mathbf{2 5 0 0} \mathbf{~ k W}$ & USD \$171.7/MWh \\
$\mathbf{2 1 , 0 0 0 ~} \mathbf{~ W W}$ & USD \$161.6/MWh \\
\hline
\end{tabular}

Source: Million Rooftop PVs 2014

By comparison, the average retail electricity price in Taiwan in 2011 was USD $\$ 0.09 / \mathrm{kWh}$ or USD \$90/MWh (Economist Intelligence Unit 2013).

\section{Outcomes}

The results from Taiwan to date suggest that despite efforts to retain the FIT in parallel with the tendering scheme, and the efforts to streamline the process for certain project types, there has been little project development in the smallest project size categories. As the Figure 1 demonstrates, the majority of the total installed capacity has been developed in the larger size categories, in particular in the commercial project size segment from $100 \mathrm{~kW}-499 \mathrm{~kW}$. Note that this includes both larger FIT projects owned by local governments, as well as projects that have participated in the tendering scheme.

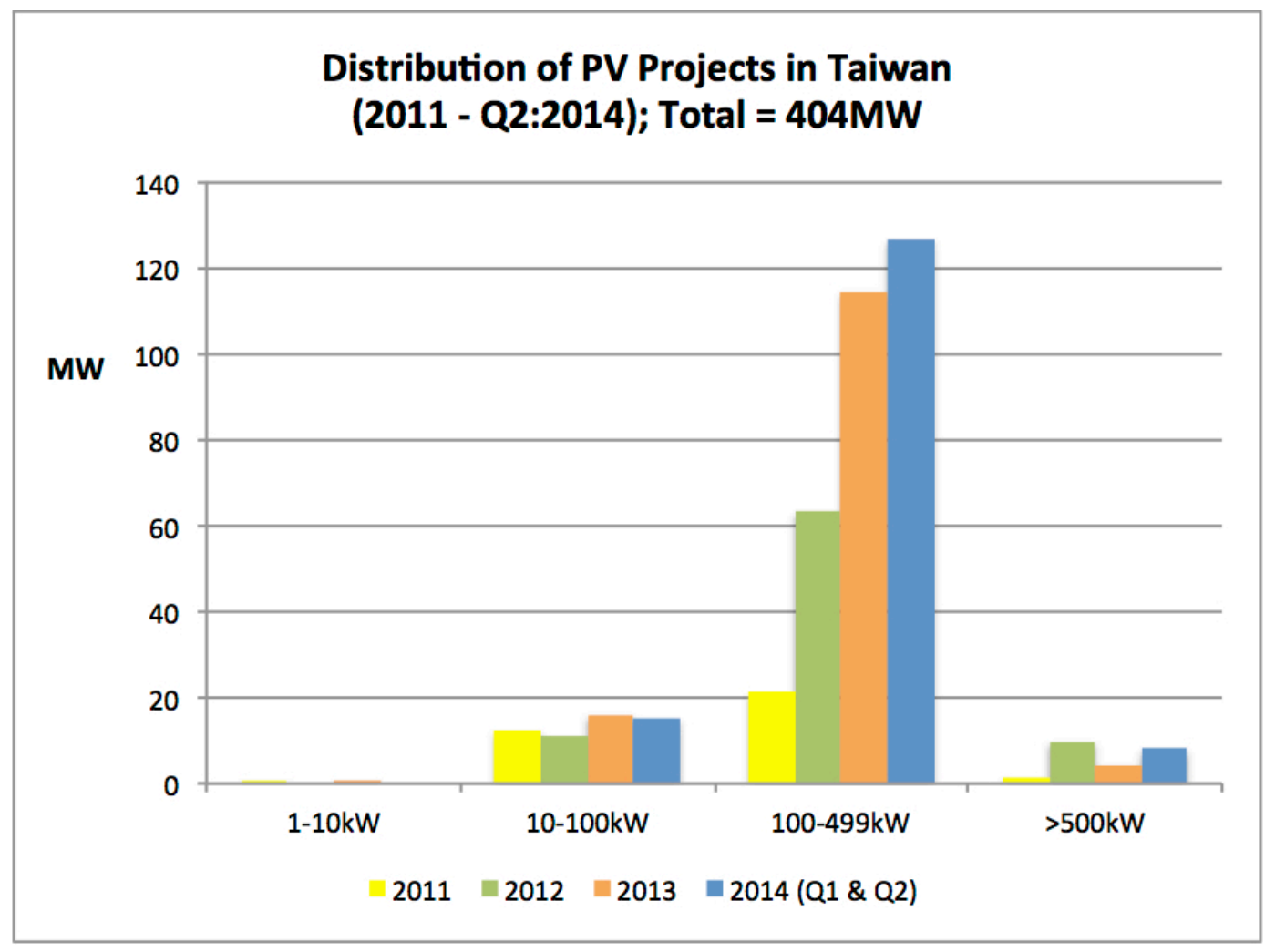

Figure 1. Distribution of PV project sizes in Taiwan (2011 - Q2:2014)

Source: Ming-Zhi Gao 2014b 
The data from Taiwan suggest that while the combined FIT and tendering scheme has proved quite successful at encouraging both new investment, and a diversity of project sizes, the overall policy framework has not been as successful as hoped at fostering projects $<10 \mathrm{~kW}$ in particular. A number of reasons have been advanced to explain this observation, including the legal and administrative difficulties associated with installing PV systems on multi-unit residential buildings, which are common in Taiwan, and the limited availability of personal loans to finance small-scale solar PV systems in the country. ${ }^{13}$ Partly in response, the government has begun to encourage financial institutions to increase their lending to the sector, a move that could help drive more project development in the smallest project sizes in the years ahead. ${ }^{14}$

\subsection{FITs and Auctions in France}

During the early 2000s, France utilized a FIT system for a range of renewable energy technologies, while also procuring some technologies such as biomass and offshore wind through tenders. The FIT applied mostly to smaller systems (under $12 \mathrm{MW}$ ), while the tendering scheme was used to procure larger projects ( $>12 \mathrm{MW})$. France's national strategy included a number of technology-specific program-size caps. The technology-specific caps were related to national targets, as determined by the multi-year investment plans for the French electricity system. If the technology-specific targets specified within the investment plans were not reached, the government retained the option of tendering out the remaining capacity (J.O. 2000, J.O. 2003).

In March 2011, France expanded the use of tenders to smaller projects and introduced a tender for rooftop solar PV projects between $100 \mathrm{~kW}$ and $250 \mathrm{~kW}$ in size (the "simplified" tendering approach), and a tender for rooftop projects between $250 \mathrm{~kW}$ and $12 \mathrm{MW}$ in size (the more "complex" tendering approach). ${ }^{15}$ Systems below $100 \mathrm{~kW}$ remain eligible for fixed FIT rates.

Table 3. Project Size and Applicable Policy in France

\begin{tabular}{ll}
\hline Solar PV Project Size & Applicable Policy \\
\hline $\mathbf{0}$ to $\mathbf{1 0 0 ~ k W}$ & Feed-in Tariff \\
$\mathbf{1 0 0}$ to $\mathbf{2 5 0} \mathbf{~ k W}$ & Simplified Tendering \\
$\mathbf{2} \mathbf{2 5 0} \mathbf{~ k W}$ & Complex Tendering \\
\hline
\end{tabular}

As seen above, France demonstrates a highly layered policy approach, where different policies are combined together to target different project size segments. Beyond providing better control over market growth, such a layered approach also enables policymakers to ensure that project development is occurring across all project size categories. Moreover, it also enables policymakers to choose the policy deemed most appropriate to encourage development in that particular size segment.

What is also noteworthy about France is that a number of additional levers are used to encourage actor diversity or to facilitate the process for smaller participants. First, in order to

\footnotetext{
${ }^{13}$ Yueh-Hsun Tsai 2014. Personal communication with Professor Yueh-Hsun Tsai, Associate Professor of Law at National Yunlin University of Science and Technology in Taiwan (September 9 2014). Note that this report has not evaluated whether the FIT level is sufficient to fully recover project development costs.

${ }^{14}$ This includes a target of "at least seven (7) billion Taiwan Dollars (TND) (USD \$230 Million) in loans" to the sector. See: http://web3.moeaboe.gov.tw/ECW/english/news/News.aspx?kind=6\&menu_id=958\&news id=3769.

${ }^{15}$ Note that the scheme was modified in 2013, but the basic distinction between projects from $100 \mathrm{~kW}$ to $250 \mathrm{~kW}$ and those above remains. Moreover, the effort to simplify the process for smaller projects is also present in both.
} 
ensure that individual actors do not string several $250 \mathrm{~kW}$ projects together on the same roof, the policy includes a limit of $250 \mathrm{~kW}$ per legal entity. Second, in order to prevent one developer from developing many projects in the same region, the policy includes a minimum distance of 500 meters (approximately 1,650 feet) between projects owned by the same legal entity. This prevents one developer, or legal entity, from owning several smaller systems in one cluster, or geographic area. Third, the simplified tendering approach significantly reduces the overall pre-qualification requirements imposed on project proponents, as well as the amount of documentation that they must provide. This makes the simplified tendering scheme closer to a feed-in tariff in certain key respects, as a far greater number of contract design elements are standardized at the outset for all project proponents. The primary functions of the simplified tendering process are therefore mostly limited to price discovery, and contract allocation. In contrast, the process for larger projects requires a significantly greater and more onerous set of application forms, including a much more detailed description of the project (manufacturer, location where the components were manufactured, etc.), as well as a thorough independent environmental assessment.

\section{Outcomes}

As seen below, France has managed to encourage a wide range of both project sizes as well as investor types to participate in its RE policy. It has accomplished this in part by retaining a simple FIT for small projects (under $100 \mathrm{~kW}$ ), with differentiated rates for a wide range of project size categories, and by introducing size-differentiated tenders for projects between 100 and $250 \mathrm{~kW}$ and between $250 \mathrm{~kW}$ and $12 \mathrm{MW}$ in size (see Figure 2).

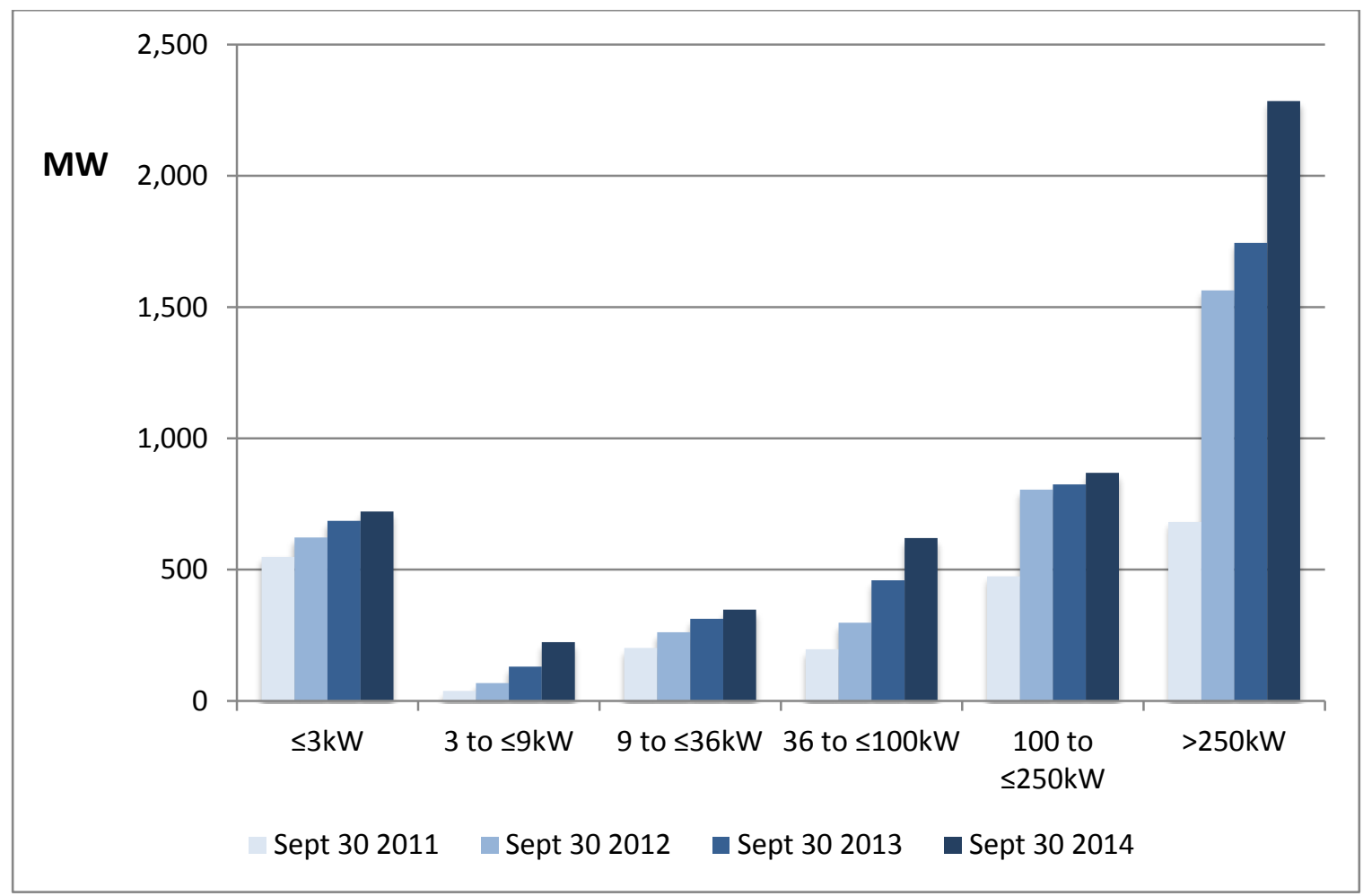

Figure 2. Breakdown of installed solar PV capacity in mainland France from 2011 to 2014 (MW)

Sources: Commissariat général du développement durable 2011, 2012, 2013, 2014 
Figure 3 shows the breakdown of project development in each category as a share of total installed capacity as of September 302014.

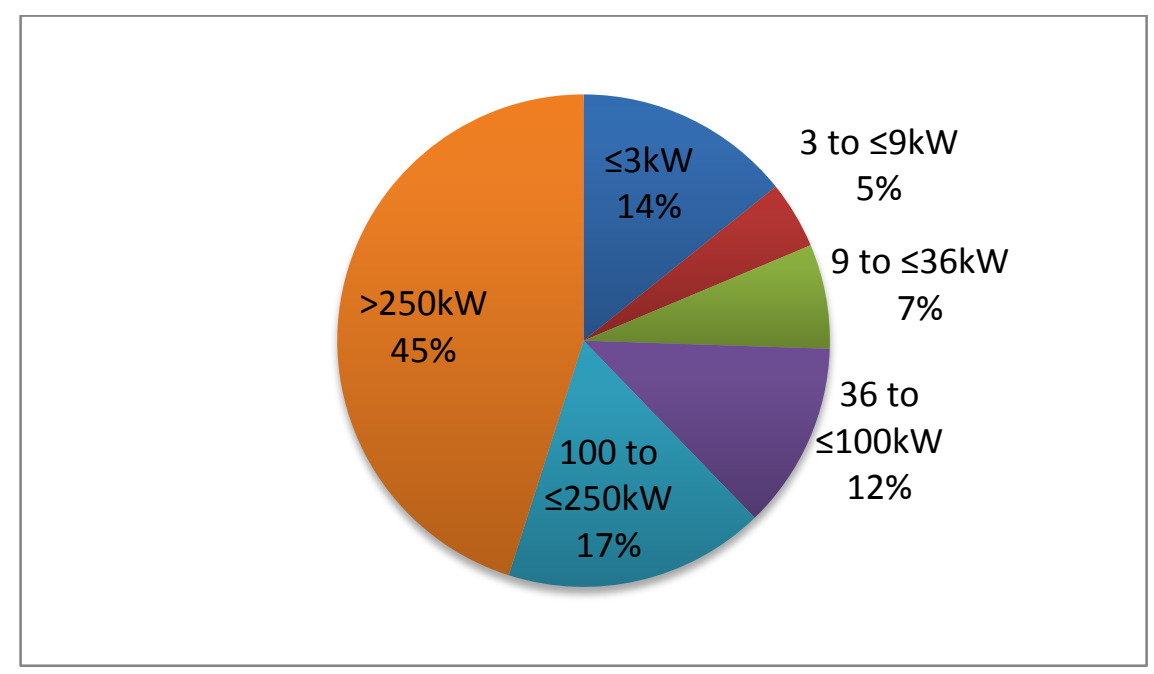

Figure 3. Breakdown of installed solar PV capacity in mainland France by project size (\%) (Sept 30, 2014)

Source: Commissariat général du développement durable 2014

As can be seen above, the installed capacity under France's FIT policy represents approximately $38 \%$ of the total, while the various tendering schemes implemented by France over the years represent the remaining $62 \%$. While the share of the total installed capacity represented by the largest projects (greater than $250 \mathrm{~kW}$ ) remains the largest, there continues to be significant development across all project sizes.

With regard to price efficiency, the results in France are also instructive.

Table 4. Purchase Prices under FITs and Tendering in France (Q3:2013)

\begin{tabular}{|l|l|l|l|}
\hline $\begin{array}{l}\text { Solar PV } \\
\text { System Size }\end{array}$ & System Type & Applicable & $\begin{array}{l}\text { Applicable Tariff in Q3: 2013 } \\
\text { Policy }\end{array}$ \\
\hline $\mathbf{0 - 9} \mathbf{~ k W}$ & $\begin{array}{l}\text { Fully building-integrated (where } \\
\text { the PV system physically } \\
\text { constitutes the roofing } \\
\text { structure) }\end{array}$ & Feed-in Tariff & $\begin{array}{l}\text { EUR 296,9/MWh } \\
\text { (USD \$378/MWh) }\end{array}$ \\
\hline $\mathbf{0 - 3 6 ~ k W ~}$ & $\begin{array}{l}\text { Roof-mounted systems (where } \\
\text { the PV system can be mounted } \\
\text { on either the roof or wall } \\
\text { structure) }\end{array}$ & Feed-in Tariff & $\begin{array}{l}\text { EUR 152,1/MWh } \\
\text { (USD \$193/MWh) }\end{array}$ \\
\cline { 3 - 4 } $\mathbf{3 6 - 1 0 0 ~ k W ~}$ & $\begin{array}{l}\text { Roof-mounted solar PV } \\
\text { systems, as stipulated in the } \\
\text { tender documents }\end{array}$ & $\begin{array}{l}\text { Feed-in Tariff } \\
\text { Te0-250 kW }\end{array}$ & $\begin{array}{l}\text { EUR 144,5/MWh } \\
\text { (USD \$184/MWh) }\end{array}$ \\
\hline $\mathbf{1 0 0}$ & Tendering & $\begin{array}{l}\text { EUR 168/MWh } \\
\text { (USD \$214/MWh) } \\
\text { (July - September 2013) }\end{array}$ \\
\hline
\end{tabular}

Source: Photovoltaique Info 2014b and CRE 2014

\footnotetext{
${ }^{16}$ For a more detailed description of the difference between simplified and fully building-integrated PV systems, see http://www.photovoltaique.info/Aujourd-hui-arrete-du-4-mars-2011 (in French) and Rickerson et al. 2014.
} 
There are a number of points to highlight here. First, the current purchase prices (in EUR/MWh) offered to fully building-integrated solar PV projects between $0 \mathrm{~kW}$ and $9 \mathrm{~kW}$ is approximately two times higher than the tariff offered to roof or wall-mounted projects up to $100 \mathrm{~kW}$. This price differential represents a significant premium for fully building-integrated projects, and a clear incentive for smaller project sizes. ${ }^{17}$ Partly as a result of this significant price incentive, France has been successful in attracting considerable investment in smaller project categories - in fact, by far the single largest number of projects in France (over 246,000 individual installations) have been installed in the $1-\mathrm{kW}$ to $3-\mathrm{kW}$ project size category (ERDF 2013).

Based on the concurrent tendering results (Q3:2013), the average weighted purchase price of tendered projects between 100 and $250 \mathrm{~kW}$ (namely, EUR 168/MWh) is significantly higher than the tariffs offered to smaller projects $(0-100 \mathrm{~kW})$ under the FIT policy (EUR 144.5/MWh to EUR 152,1/MWh). This value is also higher than average retail prices in France, which are currently EUR $0.147 / \mathrm{kWh}(\sim \mathrm{USD} \$ 0.19 / \mathrm{kWh})$ when all taxes are included (Rickerson et al. 2014). This result suggests that a significant premium is being paid for projects developed under tendering versus projects developed under the FIT in the same project size category. These results, which have been corroborated by independent analyses conducted elsewhere in Europe (Hauser et al. 2014, Frontier Economics 2014), run counter to conventional arguments that competition between developers under tendering should result in lower prices.

Recent evidence from France therefore does not support the argument that tendering necessarily results in lower procurement prices: the outcomes ultimately depend on the specific design of the policy as well as on the overall implications for investment risk, and transaction costs.

\subsection{Lessons Learned}

FITs and tendering policies are beginning to be used in combination with one another in order to meet different objectives.

The case of Taiwan suggests that even though an FIT (at over USD $\$ 0.28 / \mathrm{kWh}$ ) is offered to small solar PV projects $(<10 \mathrm{~kW})$, this incentive does not necessarily mean that a jurisdiction will be able to encourage investor participation in the project-size class. But there may also be a range of other factors, which may limit uptake in the size segment. The results in Taiwan suggest that while FITs may in theory reduce a barrier to entry, they may not be enough to ensure robust market development. Thus, more attention needs to be paid to related factors, such as the availability of debt financing, administrative barriers, the full costs of project development, as well as practical challenges such as the ease of accessing roof space.

The case of France demonstrates that retaining a FIT for smaller project sizes can help drive significant investment in projects typically owned by individual citizens or residents. In contrast with Taiwan, France has experienced more success in attracting interest in smaller projects, and has achieved more balanced project development across all project size classes. More research is recommended to determine the particular drivers behind France's success in this area.

\footnotetext{
${ }^{17}$ More specifically, for rooftop systems in which the solar PV system fully replaces (or constitutes) the roof structure itself, fulfilling the key criteria of both air- and water tightness. France has made encouraging these "fully building-integrated" PV systems a key component of its solar policy, a set of criteria and incentives that is unique in the world for building-integrated systems.
} 
In addition, it is noteworthy that the more standardized the tendering requirements become, the closer auction schemes become in certain respects to traditional feed-in tariffs: bidders are effectively bidding to obtain the rights to a long-term power purchase agreement, the same kind of standard contract commonly allocated on a first-come-first-serve basis under FIT policies. In such cases, the primary functions of an auction become twofold: price discovery, and contract allocation.

Finally, the cases of Taiwan and France both demonstrate that policy outcomes are not always as expected. For instance, in the case of France the move to auctions resulted in higher per $\mathrm{kWh}$ payments for generators, rather than lower prices. Further analysis and policy experimentation is recommended in order to better understand the reasons for this result. In this process, such analysis may yield new insights into how FITs and auctions can be combined in a more effective and impactful way in the future. 


\section{Socket Parity and Beyond}

Historically, renewable electricity policy has been motivated in part by the need to "close the gap" between the costs of renewable electricity and the costs of conventional generation. As the cost of renewable energy technologies has continued to decline and the cost of fossil and nuclear energy has continued to rise, however, important questions have emerged about how current policy frameworks might need to be adjusted or reimagined (IEA 2014; Wirth 2014). In particular, the attainment of "socket parity" - the point at which the levelized cost of electricity generation (LCOE) from on-site renewable systems is equal to, or less than, the price of purchasing electricity from the wall socket - is challenging conventional policy models for on-site generation.

This section first reviews current experience in the European and then explores how island jurisdictions are providing a laboratory for policy innovation in this area. Both Europe and island regions have been chosen primarily due to the fact that retail electricity prices in both tend to be significantly higher than the LCOE of distributed renewable electricity technologies such as solar. In some cases, customer-sited generation is more cost-effective than power generation from larger, centralized units. This makes both islands and certain European countries valuable testing grounds, as they demonstrate some of the ways in which both utilities and regulators are adapting to a world where the cost of customer-sited generation is lower than the cost of power from the grid. As the section shows, one of the consequences of this trend is that policymakers are moving beyond traditional FITs and net metering policies, and beginning to develop innovative policies that are strictly neither FITs nor net metering.

\subsection{Policy Approaches in Europe}

During the 2000s, much of Europe enacted FITs that guaranteed long-term fixed prices for electricity generation, with pricing based on each technology's generation cost (Couture et al. 2010 , Jacobs 2012). Generators would typically sell $100 \%$ of their power into the electricity grid - even if their systems were located on-site (e.g., a PV system mounted on the roof). FIT payments for on-site generation, and for PV in particular, were historically higher than retail electricity prices in most countries. However, decreases in the cost of renewable electricity have led to decreased rates. Using Germany as an example, Figure 3 illustrates, the FIT payment levels for new, small-scale PV in Germany (purple line) are now less than half the current residential retail rate (green line). The levelized cost of energy for solar PV in Germany is projected to continue to decline from $\sim \$ 0.12-\$ 0.18 / \mathrm{kWh}$ and to $\sim \$ 0.08$ $\$ 0.13 / \mathrm{kWh}$ by 2030 (Kost et al. 2013). These declines will continue to move Germany significantly beyond the point of "socket parity," leading a greater number of households and businesses to begin installing behind-the-meter solar systems to reduce the amount of power they consume from the network. This change is likely to require further policy innovation in the years ahead to better accommodate the rise of these so-called "prosumers" "18 (Rickerson et al. 2014).

\footnotetext{
${ }^{18}$ Prosumers are consumers who also produce their own power from a range of different on-site generators, including PV systems.
} 


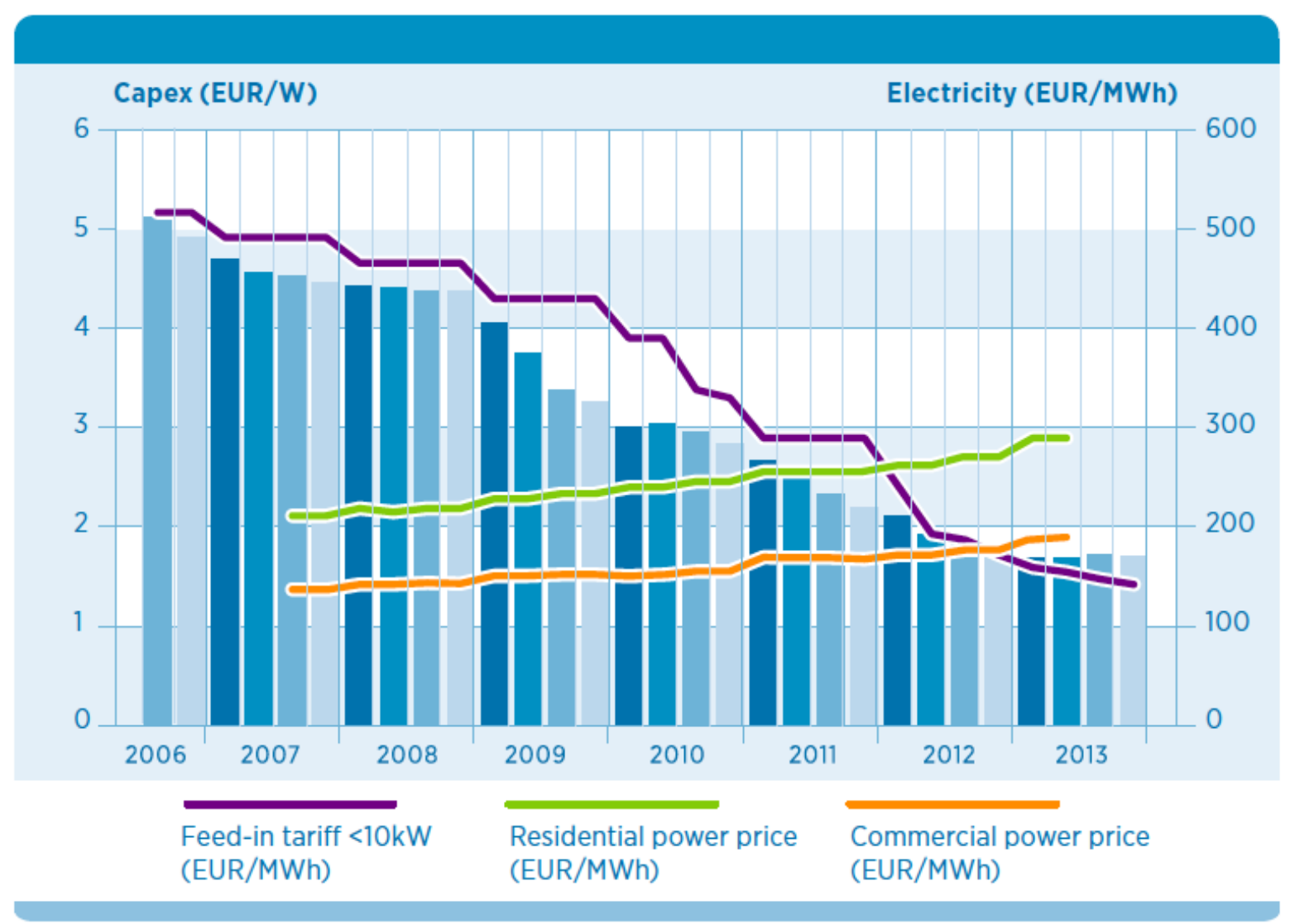

Figure 4. Development of FIT payment levels and retail electricity rates in Germany

Source: Ferroukhi et al. 2014

Germany is currently debating how to appropriately govern on-site renewable energy consumption in response to these changing dynamics. In 2009, Germany actively encouraged on-site consumption by paying generators a bonus to utilize their own electricity. ${ }^{19}$ In response to this policy - and to rising retail prices - an increasing number of on-site generators now consume their own power, rather than exporting $100 \%$ of their output to the grid, as under the FIT. While the government does not currently monitor how much solar PV generation is consumed directly on-site, estimates suggest that most new projects being installed in Germany are being configured to maximize their on-site consumption, due in large part to the growing disparity between the LCOE of on-site PV and retail prices. These estimates in turn suggest a self-consumption ratio in the range of $30 \%$ for residential projects (see Rickerson et al. 2014).

\footnotetext{
${ }^{19}$ Note that this bonus payment is no longer offered.
} 
On-site generation is beginning to cause national policy challenges, however. The abovemarket cost of historical FIT payments is currently recovered through a surcharge that is included in retail electricity rates. This surcharge is currently USD $\$ 0.08 / \mathrm{kWh}$ (EUR0.0624/kWh). By consuming their own output, on-site generators purchase less power from the grid and therefore avoid paying this surcharge. In response, the latest amendment to Germany's national FIT law requires on-site generators to pay $30 \%$ of this surcharge (rising to $40 \%$ as of 2017) for each kilowatt-hour of electricity they consume on-site. Installations below $10 \mathrm{~kW}$ are exempt from the regulation. ${ }^{20}$ Other European countries are exploring how to balance support for on-site energy consumption with decreased retail electricity purchases in their markets. An increasing number of U.S. states are also grappling with similar questions since most U.S. states allow on-site generators to engage in some form of net metering (Barnes et al. 2013).

The issues related to supporting and managing on-site energy consumption are highly complex, and raise questions such as how to value the benefits that on-site generation creates for other stakeholders, how to recover or allocate the costs that on-site generators avoid paying for (such as grid costs), and how to amend existing regulatory frameworks as on-site generators scale up in the future (Bird et al. 2013; Hansen et al. 2013; Rickerson et al. 2014).

\subsection{Policy Approaches on Islands}

This section looks specifically at island jurisdictions. Most islands depend primarily on liquid fuels such as diesel for electricity generation and have some of the highest retail electricity prices in the world as a result (Rickerson et al. 2012). With increasing demand from their citizens for renewable electricity generators, island policymakers are evaluating whether to adopt traditional feed-in tariffs or net metering, or whether to introduce innovations that are more adapted to their specific contexts. In the absence of appropriate, off-the-shelf terms to describe their new policies, they have often simply adopted the policy labels from the existing toolkit, occasionally generating confusion as the new policies no longer resemble their traditional predecessors.

When island jurisdictions face high retail electricity costs, which can exceed USD $\$ 0.50 / \mathrm{kWh}$, the cost to produce on-site renewable electricity can be lower than the retail rate of electricity and even below the utility's cost of generation. In such environments, offering to purchase (or credit) on-site generation at the full retail rate, or even at the full avoided generation cost, may result in on-site producers being over-compensated. At the same time, renewable electricity that is below utility avoided cost may create opportunities for ratepayer savings rather than incurring additional ratepayer costs.

In reaction to these challenges and opportunities, island jurisdictions have been developing policies that combine elements of FITs and net metering in innovative ways. This section briefly reviews current practice in four island jurisdictions to highlight the different approaches that policymakers are taking. These jurisdictions include the Cayman Islands, Grenada, and the Seychelles. These islands were chosen in order to reflect a diversity of current policy approaches, although there are currently many other innovations taking place around the world.

Table 5 provides a summary of the key policy elements, and more detailed descriptions of each policy follow the table.

\footnotetext{
${ }^{20}$ Even though the effects of this new regulation are not yet entirely clear, it can be expected that investment into new solar PV systems will remain financially attractive due to the large gap between the retail electricity price and the LCOE of solar PV. However, this depends on the self-consumption ratio and the size of the PV system.
} 
Table 5. Summary of On-site Generation Policies in the Cayman Islands, Grenada, and the Seychelles

\begin{tabular}{|c|c|c|c|c|c|c|}
\hline Country & $\begin{array}{l}\text { Policy } \\
\text { mechanism }\end{array}$ & $\begin{array}{l}\text { On-site } \\
\text { Consumption? }\end{array}$ & System size cap & Program Cap & $\begin{array}{l}\text { Compensation } \\
\text { structure }\end{array}$ & Compensation amount (USD) \\
\hline $\begin{array}{l}\text { Cayman } \\
\text { Islands }\end{array}$ & CORE Tariff & Yes* $^{*}$ & $\begin{array}{l}\text { Residential: } 20 \mathrm{~kW} \text {, or } \\
\text { peak load } \\
\text { Commercial: } 100 \mathrm{~kW} \text {, or } \\
\text { peak load }\end{array}$ & $2 \mathrm{MW}$ & $\begin{array}{l}\text { Cash payment for } \\
\text { metered output of } \\
\text { PV system }\end{array}$ & USD $\$ 0.47 / \mathrm{kWh}$ for 20 years \\
\hline Grenada & $\begin{array}{l}\text { Renewable } \\
\text { Standard } \\
\text { Offer }\end{array}$ & No & $100 \mathrm{~kW}$ & $\begin{array}{l}2.5 \% \text { of annual } \\
\text { electricity demand }\end{array}$ & $\begin{array}{l}\text { Cash payment for } \\
100 \% \text { of power }\end{array}$ & $\begin{array}{l}\text { SUSD } 0.17 / \mathrm{kWh} \text { for } 10 \text { years, or } \\
\text { Average avoided cost of fuel for } \\
\text { previous } 12 \text { months }\end{array}$ \\
\hline Seychelles & $\begin{array}{l}\text { Net-Metering } \\
\text { Program }\end{array}$ & Yes & $\begin{array}{l}\text { Commercial: } 50 \% \text { of on- } \\
\text { site energy consumption } \\
\text { for }\end{array}$ & None & $\begin{array}{l}\text { Cash payment for } \\
\text { excess generation }\end{array}$ & $88 \%$ of the avoided fuel cost \\
\hline
\end{tabular}

* Power can be consumed on-site but does not offset retail electricity purchases. 
Cayman Islands. The Cayman Islands have adopted a unique on-site generation policy with the Customer-Owned Renewable Energy (CORE) tariff program. Generators can choose whether to connect in front of the meter (as under a traditional FIT) or behind the meter (as is typically done with net metering). Under both configurations, however, generators are billed at the retail rate for $100 \%$ of the power that is consumed on-site. This arrangement applies whether that electricity is purchased from the grid or generated by the on-site PV system. Electricity generated by the PV system is then compensated at a rate of $\sim \$ 0.47 / \mathrm{kWh}$ for residential systems for a 20-year period, whether or not that power is consumed on-site or exported directly into the grid. For comparison, the residential retail rate was USD $\$ 0.44 / \mathrm{kWh}$ in the first quarter of 2014. This arrangement provides generators with the flexibility to use their PV system to charge a battery for back-up power (i.e., in the behind-the-meter configuration), while also ensuring that on-site generators pay the retail rate for all the power they consume. At the same time, the policy creates an incentive for customer-sited renewable energy since the CORE tariff is higher than the retail electricity rate. System size is limited either by a size cap or by on-site peak load, whichever is less, and the total amount of capacity installed that can utilize the CORE tariff is limited to $2 \mathrm{MW}$. At the end of 2013, there were 27 systems totaling $234 \mathrm{~kW}$ installed, with an additional 15 projects totaling $373 \mathrm{~kW}$ under design or construction (Caribbean Utilities Company 2014).

Grenada. Grenada instituted a net metering policy in 2007, which allowed generators to receive credit for excess generation at the full retail rate of electricity. The retail rate in Grenada was USD $\$ 0.37 / \mathrm{kWh}$, and it was determined that generators were likely capturing excess profits while the utility lost an estimated $\$ 500,000$ in revenue each year. In order to limit excess profits and reduce utility revenue loss, the utility switched to a net billing policy under which generators must purchase $100 \%$ of their power at the full retail rate and export $100 \%$ of their power to the grid. ${ }^{21}$ The program is currently limited to $2.5 \%$ of annual electricity demand. Generators can choose to export at either a fixed rate of USD $\$ 0.17 / \mathrm{kWh}$ (XCD.45/kWh) for ten years or at the utility's average avoided cost (which is adjusted annually) (GRENLEC 2011). Of note, the switch to avoided cost has slowed market growth at the residential level significantly.

While island policymakers and much of the literature often refer to Grenada's policy as net billing, it should be noted that in this instance, the term "net billing" is used differently than it is in the United States (where the term originated). In the United States, net billing policies allow on-site generators to offset retail electricity purchases - the key difference between net metering and net billing being that under net billing, the rate at which generators are compensated, or credited, differs from the retail rate they pay. The policy in Grenada, by contrast, does not allow any on-site consumption. In addition, the requirement that $100 \%$ of power be exported also distinguishes Grenada's policies from feed-in tariffs in countries such as Australia (where generators can choose to consume some of their power on-site).

Seychelles. The Seychelles introduced a "Net-Metering Program" for on-site generators in January 2014. Under the program, generators can offset their retail electricity purchases from the grid. Excess power, however, is then sold at a "net feed-in tariff" rate equal to $88 \%$ of the utility's cost of fuel. Excess power is not compensated at $100 \%$ of the avoided fuel cost in order to account for electricity grid losses (Ministry of Environment and Energy 2014). At present, the avoided fuel cost equates to approximately $\$ 0.19 / \mathrm{kWh}$. System sizes are capped at $50 \%$ of on-site energy consumption for commercial systems larger than $10 \mathrm{~kW}$. Systems smaller than $10 \mathrm{~kW}$ are not capped. The Seychelles is currently exploring whether to institute

\footnotetext{
${ }^{21}$ Note that the program is officially called the Renewable Standard Offer.
} 
a policy under which $100 \%$ of power would be sold into the grid, similar to the policy currently in place in Grenada.

\subsection{Lessons Learned}

There are a number of lessons that emerge from the case of Germany. In recent years, the LCOE of solar PV has fallen far below the retail price of electricity, making it possible for both residential and commercial customers to offset their own consumption using on-site PV. After incentivizing on-site consumption for a few years, Germany has now reversed course, and has started to require these prosumers to share in the costs of the EEG surcharge. This dynamic highlights the challenges that policymakers face in the years ahead in controlling the rate of uptake of customer-sited solar PV in an environment of decreasing PV costs, and rising retail rates. Germany's decision to require PV prosumers to share in the costs of the EEG surcharge is merely the beginning, as more jurisdictions around the world design new ways either to slow the pace of growth in this market segment, or to require prosumers to contribute more to cover fixed electricity system costs. It is too early to say whether and to what extent these attempts will be successful.

The emerging experience on islands, however, highlights a number of important lessons:

- No "right" or "best" policy. The islands have generally opted not to implement traditional net metering or FIT policies. Instead, they have introduced policies that combine elements of FITs and net metering in new ways. In some cases, such as the Cayman Islands, these policy structures represent unique approaches globally. On the other hand, a clear common practice, let alone a "best" practice, has not yet emerged and additional research into the pros and cons of different policy approaches within island contexts would be useful.

- Utilities are designing polices to address revenue loss. Grenada's utility has shifted from a net metering policy to a policy that requires $100 \%$ of PV output to be sold into the grid. Part of the intent behind this shift is to require generators to pay the full retail rate and limit the impact of reduced electricity sales on both other ratepayers and utility shareholders. The Seychelles is considering a similar approach, while the Cayman Islands have created a globally unique solution to this issue. Restricting the amount of power that can be consumed on-site, however, raises legal, moral, as well as philosophical questions as to whether utility customers have the "right" to consume their own power on-site. This issue is contentious in Grenada and similar debates may occur elsewhere as other countries contemplate " $100 \%$ sale" requirements.

- Avoided cost is emerging as a cost benchmark. Grenada and the Seychelles have linked generator compensation to costs that the utility avoids, such as fuel costs, when it does not have to generate the power. The use of avoided cost in islands - and eventually in non-island countries - could serve as an attractive payment rate as renewable energy costs continue to fall below retail rates. At present, however there is not sufficient evidence about the performance of these policies to draw broad conclusions about their effectiveness. At least in the case of Grenada, the switch to avoided cost has slowed market growth at the residential level significantly.

- Terminology is not applied in a standard manner. The policy names used within these island jurisdictions illustrate how traditional policy labels are being used inconsistently. As discussed above, the term net billing in Grenada has significant design differences from net billing policies in the United States. The Net-Metering Program in the Seychelles, meanwhile, describes its crediting arrangement a "net excess feed-in tariff," thus borrowing terminology from both policy traditions 
simultaneously. These uses of terms can make cross-comparisons using the standard labels challenging. Policy comparisons instead require more detailed consideration of policy structure (see Table 5) in order to be useful.

Many island jurisdictions are entering periods of transition for customer-sited renewable electricity policy as fuel costs rise and renewable energy technology costs fall. Many mainland jurisdictions are not far behind. As the LCOE of customer-sited renewable electricity technologies continues to fall below retail electricity prices in jurisdictions like Germany, the Caribbean region, the Indian Ocean, as well as the Pacific Islands region, policymakers are beginning to respond by developing policies that lie somewhere between traditional net metering and FITs. 


\section{Integrating Renewable Electricity into Wholesale Markets}

Many countries around the world have started to liberalize their electricity markets over the past decades. More recently, an increasing number of developing countries are taking steps towards market liberalisation in order to attract foreign investment and meet increasing electricity demand (Wamukonya 2003; Gratwick and Eberhard 2008).

With shares of renewable electricity sources increasing, several jurisdictions around the globe have started to better integrate renewables into the existing power sector structure, i.e., integrating renewables into wholesale markets. Until recently, this policy challenge has primarily concerned decision makers in Europe and in certain parts of the United States. However, policymakers in emerging economies and developing countries will be facing similar design issues once their share of renewable electricity rises and if, or when, wholesale competition is more fully introduced. In this section, we focus on the European debate because the policy innovations under consideration were first implemented in the European Union. As highlighted above, the examples from Europe may be valuable to emerging markets that are considering, or that are in the process of, introducing wholesale electricity markets.

The basic rationale for exposing electricity producers to (spot) market prices is to encourage the alignment of power generation with electricity demand. Traditional power producers can at least theoretically - react to price signals from wholesale power markets by increasing or decreasing their power output and by designing their power plant in order to better align power output with typical demand patterns. This is much more difficult with non-dispatchable generation such as traditional solar PV and wind power. ${ }^{22}$ In addition, spot market prices in fully liberalized markets should indicate whether investment in new power generation capacity is needed (based on current prices and predictions of future spot market price evolution). Any investor will need to decide on whether the expected prices will allow the recovery of costs over the lifetime of a power plant.

Aspects of this discussion can be seen in the debate between FITs and tradable green certificates (TGCs) in the EU over the last decade.

\subsection{Policy Conflict in the European Union: FITs versus TGCs}

For many years, the policy discourse in the European Union was dominated by a confrontation between proponents of tradable green certificates and proponents of FITs (Lauber 2004; Ringel 2006; Fouquet and Johansson 2008; Jacobsson et al. 2009). This confrontation was driven by the apparent trade-off between two seemingly contradictory policy objectives:

- Creating a high degree of investment security to drive renewable electricity producers through fixed, long-term prices

- Ensuring compatibility with a fully liberalized European electricity market and its short-term trading requirements.

FITs were argued to be more consistent with the former objective, whereas tradable credits were argued to be more consistent with the latter.

\footnotetext{
${ }^{22}$ Options may include, for instance, facing solar PV systems east or west instead of south. While this could help avoid the daytime PV supply peak, and the associated wholesale market price trough, it would also reduce overall output from the PV system.
} 
The European Commission had called for the introduction of tradable green certificates at the national level in the mid-1990s (EU Commission 1996). Under this scheme, power producers would sell their electricity directly on the spot market. On top of the revenues from spot market sales, power producers would be given the right to sell "green electricity" certificates. It was assumed that tradable credit prices would be determined in short-term markets in response to supply and demand, similar to the manner in which electricity is traded (Sovacool 2011; Jacobs and Sovacool 2012). The concept of tradable credits was first introduced in the United States as part of state-level electricity liberalization and restructuring efforts (Rader \& Norgaard 1996).

Despite the European Commission's call for tradable credits, policymakers in the European Union, such as Denmark, Spain and Germany, were already successfully promoting renewable electricity market growth with instituted long-term, fixed price FITs. These policies explicitly shield renewable electricity producers from the fluctuations of the wholesale spot market by providing suppliers with both a purchase guarantee, as well as a fixed long-term price for their output. This trend led to the emergence, in effect, of two electricity markets, one for renewable electricity sources and the other for every other generation technology. However, the preference for FITs persisted as policymakers prioritized investment security over the desire to foster so-called "market integration" by forcing renewable producers onto the spot markets. As of 2013, FITs remained the dominant renewable electricity policy instrument in 20 out of $28 \mathrm{EU}$ member states.

\subsection{Financing RE Projects via Spot Market Sales?}

Spot markets establish a uniform price per kilowatt-hour paid to all power producers - the socalled "clearing price" - irrespective of their individual generation costs. This price is determined via anonymous bids. Spot market prices are usually auctioned on an hourly basis, meaning that potential revenues for power producers change hourly and in some cases even on a sub-hourly basis (Borenstein 2000; Joskow 2008). Such a volatile pricing environment creates a substantial risk for all power producers that need to finance their investment via spot market sales of electricity over the lifetime of their power plant. This volatility, in turn, generally increases the cost of capital.

In addition, renewable electricity technologies, especially solar PV and wind energy, face relatively high shares of capital expenditures in relation to operation expenditures. In fully liberalized markets, all power producers need to re-finance their capital expenditures and their operating expenditures via surplus revenues from market sales. This implies a higher risk for technologies with high shares of capital expenditures. Short- and long-term price volatilities of the spot-market are a bigger risk for wind and PV producers than for gas-fired power producers. Put simply, an operator of a gas-fired power plant can still decide not to operate the plant if market prices are below the costs for fuel (and carbon dioxide). Therefore, refinancing power plant via spot market sales creates a bias towards technologies with a low share of capital costs (and a high share of fuel costs) (2015). 


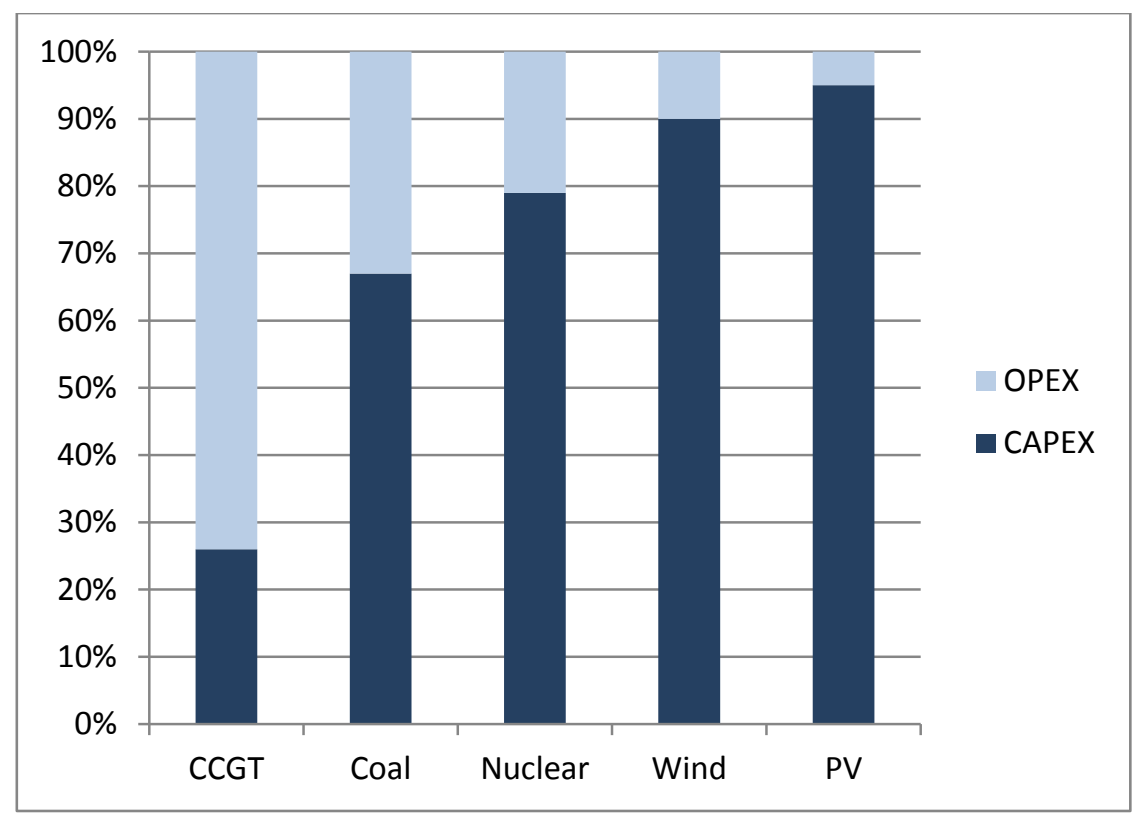

Figure 5. Share of fixed versus variable costs of selected power generation technologies

Source: Authors based on EIA 2013

Moreover, an increasing share of wind energy and solar PV with very low marginal costs reduces the spot-market price. This so-called "merit-order-effect" has been observed in many jurisdictions with a high share of variable renewables in the system (Sensfuß and Ragwitz 2007; Sáenz de Miera et al. 2008; Ray et al. 2010). Increasing shares of wind and solar PV on the market results in lower spot market prices during windy or sunny hours and thus erode the basis for financing these power plants via spot market sales in the future. Partly as a result, it has become extremely difficult to finance new electricity generation capacity of any kind (whether fossil, nuclear, or renewable) by relying solely on the spot market.

\subsection{Designing Premium FITs in the EU}

In the past years, policymakers in several European countries have tried to reconcile both policy objectives: investment security and wholesale market integration. They have come up with policy instruments that require renewable electricity producers to sell their electricity on wholesale markets but which allow for higher revenue security than usual spot market sales. These instruments have been given different names: contracts for differences in the United Kingdom (UK), market premiums in Germany and premium FITs in Spain. ${ }^{23}$ As of 2014, six European countries made use of this type of hybrid support mechanism. However, the specific design differs from one country to another.

The first premium FITs in Spain consisted of a fixed premium payment on top of the wholesale market prices. For instance, wind power producers would receive additional 2.9 EURcent/kWh on top of the wholesale market price. This payment was determined administratively. However, this design led to overcompensation for wind producers in years of high wholesale market prices and a substantial risk for power producers in the case of falling wholesale prices. Therefore, Spanish policymakers implemented a cap and floor price (Bechberger 2009; Jacobs 2012).

\footnotetext{
${ }^{23}$ Spain was the first country to establish premium feed-in tariffs in 1998 (Jacobs, 2012). However, it abandoned this financing mechanism in 2013 because of its higher costs in contrast to fixed tariff payment.
} 
Contracts for differences, as they are currently planned in the UK, guarantee renewable electricity generators a fixed "strike price" for their electricity, after participation in the wholesale market. Consequently, revenue security is similar to that under traditional FIT arrangements, although the strike price is determined as a monthly average payment benchmark and power producers need to find their own buyer of renewable electricity (instead of a single buyer under standard FIT contracts). Generators sell electricity competitively into the spot market, and then receive an ex post defined premium payment to "close the gap" between the (usually) above-market strike price and the wholesale market price. The incentive payment therefore fluctuates depending on the competitive electricity price. This is also why this type of finance mechanism is sometimes called "spot market gap" model (Couture and Gagnon 2010). It should be noted that premium payments are not necessarily above the spot market electricity price. The planned contracts for differences scheme in the UK obliges power producers to pay in case spot market prices are above the strike price (i.e., the defined premium payment level) (UK Government 2014) (Sherry 2013). This mechanism was introduced in order to reduce costs for final electricity consumers.

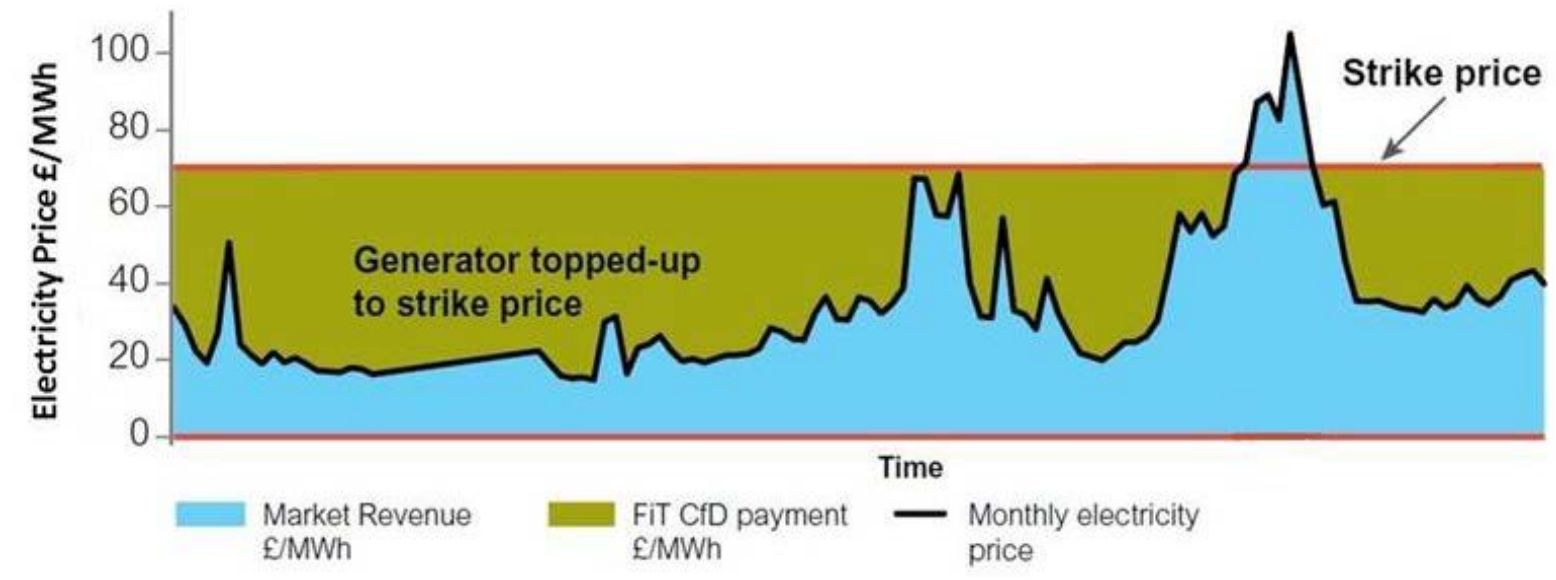

Figure 6. Functioning of planned contracts for differences in the UK

Adapted from Department of Energy and Climate Change 2011

In Germany, a technology-differentiated approach was implemented in order to take the specific characteristics of weather-dependent renewables (wind and solar PV) and dispatchable renewables (biomass, biogas) into account. Similar to the contracts for differences mechanisms in the UK, the premium payment is determined ex-post (i.e., at the end of each month).

In the case of biomass and biogas, power producers receive the hourly changing wholesale market price as one payment component, which is later topped up by the ex-post defined premium payment. The rational for this regulation is that these power producers can react towards short-term price fluctuations by turning their power production up or down. Since wind and solar PV producers have only very limited capacity for this type of dispatch (they produce power when the sun is shining and when the wind is blowing), they are not confronted with hourly price fluctuation but instead receive a monthly average wholesale market price. The regulator determines a benchmark price based on the hours when solar PV was produced and fed into the grid. This so-called "market price solar PV" and "market price wind energy" is generally below the average monthly wholesale price because of the aforementioned merit-order-effect. Spot market prices are usually lower than average when a lot of wind energy and solar PV is sold in the spot market. 


\subsection{Lessons Learned}

The case of premium FITs illustrates the extent to which policymakers have managed to reconcile different policy objectives though hybrid policy design. Policymakers have attempted to design policies that maintain a relatively high degree of revenue security for renewable electricity producers while simultaneously requiring producers to interact with wholesale spot markets. It is difficult to determine which share of fluctuating renewables will require these kinds of policy measures, or others like them, because this depends on a host of factors, including the existing grid infrastructure (e.g., the size of the grid and interconnections with neighbouring countries) as well as the flexibility of the electricity system (e.g., the potential for balancing the fluctuations with readily dispatchable resources such as hydro power or gas turbines, or with dispatchable loads, such as desalination plants).

The design of premium FITs differs from one country to the next and confronts renewable electricity producers with different levels of risk. For instance, pre-determined premium payments as they have existed in Spain confront renewable electricity producers with higher revenue risk than premium payments defined after the fact (i.e., after the electricity is sold on the spot market), as found in Germany and in the UK. The case of Germany also illustrates that technology-specific approaches can take the different characteristics of renewable electricity technologies into account.

Premium FITs have managed to increase the share of power sold on the wholesale market. Increasing liquidity on wholesale markets is critical in liberalized power markets. In addition, renewable energy producers are being incentivized to curtail during hours of negative electricity prices, for instance, if power supply exceeds demand.

From a policy perspective, policymakers need to weigh the benefits of including renewable energy producers in wholesale spot markets against the potential impacts on renewable energy development.

- Wholesale spot markets were designed around traditional electricity generation. Since renewable energy technologies are capital intensive, reliance on spot markets for financing significantly impacts project development and financing.

- Wholesale markets treat all electrons the same. In other words, they provide no financial benefit to electricity with positive environmental attributes. In addition, wholesale markets in general can put intermittent resources at a disadvantage against dispatchable resources since spot markets often are combined with future contracts for services that are more complicated for intermittent generation.

- Many countries have created hybrid versions of FITs or other policies to enable participation of renewable energy in spot markets while ensuring renewable energy production is a viable economic option.

- The gradual integration of higher shares of renewable electricity sources into spot markets may eventually require making structural changes to electricity spot market design (e.g., shorter intra-day markets in order to increase the accuracy of wind and solar forecasts, as well as shorter gate closing times). 


\section{Conclusion}

This paper has shown that the distinctions between the traditional policy labels such as FITs, auctions, and net metering are beginning to break down as policymakers adapt policy frameworks to new market realities. As a result, policy comparisons that rely on the conventional labels may no longer be appropriate, or advisable. The recent policy innovations surveyed in this paper may therefore point the way toward the next generation of renewable electricity policies.

These innovations have been driven by a number of factors, including the decreasing costs of renewable energy technologies, the difficulty in adjusting policies to rapidly changing market conditions, and by the growing share of renewable electricity in some countries' overall electricity mix. Collectively, these factors are leading policymakers to develop new frameworks that are better adapted to changing market circumstances. In some cases, this has meant creating new policies that lie somewhere between traditional FITs and net metering or auctions, while in others, it has meant exposing renewable electricity producers to spot market signals while attempting to retain some minimum level of revenue certainty by adopting socalled premium FITs.

This paper has examined several cases of innovative renewable electricity policies around the world. First, it demonstrated that FITs and auctions are not mutually exclusive; they can in fact be combined together in a variety of ways. By looking at both France and Taiwan, the paper showed that the two procurement strategies are being combined to reconcile two seemingly contradicting policy objectives: cost efficient renewable energy support on one hand, and ensuring investor and project size diversity on the other. While Taiwan was successful in combining FITs and auction schemes together, it continues to have difficulties attracting investment in the smallest project sizes. The experience in Taiwan indicates that a FIT alone, despite offering streamlined administrative procedures, does not ensure robust market development in smaller project sizes and that related factors can significantly restrict development, as well as investor participation.

In comparison with Taiwan, France has experienced greater success at encouraging investment in the smaller project sizes, in particular those typically owned by individual citizens or residents $(<9 \mathrm{~kW})$. Moreover, results from France in 2013 suggest that tendering does not necessarily result in lower prices for consumers. This result suggests that further experience and policy improvement may be required in order to combine FITs and auction schemes in more effective and impactful ways.

Second, we analysed both island regions and Germany for insights into how policies are being adapted when the LCOE of on-site solar PV systems is below the cost of power from the grid. The achievement of so-called "socket parity" is causing FITs, net metering, and selfconsumption to be revisited both in Germany and in island regions around the world. Where the LCOE of solar PV has fallen below the retail electricity rate, it creates a strong incentive for direct on-site PV consumption among both residential and commercial customers in particular. In this environment, policymakers are seeking to balance enabling on-site renewable electricity while limiting disproportionate benefits to prosumers. 
In island regions, new policies are emerging that compensate prosumers for the power they export to the grid at a rate that is below the retail price of electricity, as well as below the avoided cost of generation (or fuel). In the process, islands are giving rise to a range of policy innovations that lie somewhere between traditional FITs and net metering policies. Such hybrid policies could become more widespread as the cost of distributed generation options continues to fall in markets around the world.

Third, the paper looked at the implementation of premium FITs in the EU as a strategy to reconcile different policy objectives, namely maintaining a high degree of revenue security for renewable electricity producers while simultaneously requiring such producers to interact with wholesale spot markets. Currently, several European member states are experimenting with different design features, exposing renewable electricity producers to different levels of price risk. This signals a decisive shift away from traditional FIT policies, which provided both a fixed price and a purchase guarantee over a pre-determined period of time, and a further example of the breakdown of the traditional policy definitions and the rise of hybrid policy designs.

This paper has argued that the breakdown in the conventional policy labels represents an important shift in renewable electricity policy, one that policymakers, analysts, government officials, and investors around the world need to better understand. By cracking open the conventional toolbox and combining different policy design elements in innovative ways, policymakers are beginning to create a new policy kit, one that is arguably better adapted to the new market realities. 


\section{References}

Barnes, J., Culley, T., Haynes, R., Passera, L., Wiedman, J., Jackson, R. (2013). Freeing the grid 2013: Best practices in state net metering policies and interconnection procedures. Latham, NY and San Francisco, CA: Interstate Renewable Energy Council and the Vote Solar Initiative.

Bechberger, M. (2009). Erneuerbare Energien in Spanien, Erfolgsbedingungen und Restiktionen. Stuttgart, Germany, ibidem-Verlag.

Bird, L., McLaren, J., Heeter, J., Linvill, C., Shenot, J., Sedano, R., Migden-Ostrander, J. (2013). Regulatory considerations associated with the expanded adoption of distributed solar (NREL/TP-6A20-60613). Golden, CO: National Renewable Energy Laboratory.

Borenstein, S. (2000). Understanding competitive pricing and market power in wholesale electricity markets. The Electricity Journal 13(6); pp. 49-57.

Butler, L., Neuhoff, K. (2008). Comparison of feed-in tariff, quota and auction mechanisms to support wind power development. Renewable Energy (33); pp. 1854-1867.

Caribbean Utilities Company. (2014). 2013 annual report. Grand Cayman, Cayman Islands.

Carmichael, A. (2010). Comments of Vote Solar in response to the Notice of Request for Comments (Investigation regarding feed-in tariffs, Docket No. 09-11004) (p. 20). Carson City, NV: Public Utilities Commission of Nevada.

Commissariat general au développement durable. (2014). Tableau de bord éolienphotovoltaïque: Troisième trimestre 2014 - Service de l'observation et des statistiques.

Available at: Commissariat général du développement durable 2014

http://www.statistiques.developpementdurable.gouv.fr/fileadmin/documents/Produits editoriaux/Publications/Chiffres et statistique s/2014/chiffres-stats584-eolien2014t3-novembre2014.pdf.

Commissariat general au développement durable. (2013). Tableau de bord éolienphotovoltaïque: Troisième trimestre 2013 - Service de l'observation et des statistiques.

Available at: Commissariat général du développement durable 2014

http://www.statistiques.developpementdurable.gouv.fr/fileadmin/documents/Produits editoriaux/Publications/Chiffres_et statistique s/2013/chiffres-stats469-eolien2013t3-novembre2013.pdf.

Commissariat general au développement durable. (2012). Tableau de bord éolienphotovoltaïque: Troisième trimestre 2012 - Service de l'observation et des statistiques.

Available at: Commissariat général du développement durable 2014

http://www.statistiques.developpement-

durable.gouv.fr/fileadmin/documents/Produits editoriaux/Publications/Chiffres et statistique s/2012/chiffres-stats373-eolien-photovoltaique2012T3-novembre2012.pdf.

Commissariat general au développement durable. (2011). Tableau de bord éolienphotovoltaïque: Troisième trimestre 2011 - Service de l'observation et des statistiques.

Available at: Commissariat général du développement durable 2014

http://www.statistiques.developpement-

durable.gouv.fr/fileadmin/documents/Produits editoriaux/Publications/Chiffres et statistique s/2011/Chiffres $\% 20$ et $\% 20$ stats $\% 20267 \% 20$ Eolien $\% 20$ photovol $\% 202011 \mathrm{~T} 3 \% 20$ -

\%20novembre\%202011.pdf. 
Couture, T., Cory, K., Kreycik, C., Williams, E. (2010). A policymaker's guide to feed-in tariff policy design. NREL/TP-6A2-44849. Golden, CO: National Renewable Energy Laboratory.

Couture, T., Y. Gagnon (2010). An analysis of feed-in tariff remuneration models: Implications for renewable energy investment. Energy Policy 38(2); pp. 955-965.

Cozzi, P. (2012). Assessing reverse auctions as a policy tool for renewable energy deployment (No. 007). Medford, MA: Center for International Environment \& Resource Policy (CIERP), The Fletcher School at Tufts University.

CRE. (2014). Coûts et rentabilité des énergies renouvelables en France métropolitaine: Éolien terrestre, biomasse, solaire photovoltaïque. Available at:

http://www.cre.fr/documents/publications/rapports-thematiques/couts-et-rentabilite-des-enren-france-metropolitaine/consulter-le-rapport.

Del Río González, P. (2008). Ten years of renewable electricity policies in Spain: An analysis of successive feed-in tariff reforms. Energy Policy (36); pp. 3345-3359.

Department of Energy and Climate Change. (2011). Planning our electric future: A white paper for secure, affordable and low-carbon electricity. London: Stationery Office.

DSIRE. (2014). Available at:

http://www.dsireusa.org/incentives/incentive.cfm? Incentive Code $=$ VI07F\&re $=0 \& e e=0$.

Economist Intelligence Unit. (2013). Turning on the lights. Available at: http://www.eiu.com/industry/article/1670907751/taiwan-electricity-turning-on-thelights/2013-09-02.

EIA. (2013). Levelized Cost of New Generation Resources in the Annual Energy Outlook 2013. Washington DC U.S. Energy Information Administration.

ERDF. (2013) Available at:

http://www.erdfdistribution.fr/medias/Donnees_prod/parc_prod_decembre_2013.pdf.

EU Commission. (1996). Energy for the future - Renewable sources of energy. Greenpaper for a community strategy. COM(96)576 final. European Commission. Brussels.

Ferroukhi, R., Gielen, D., Kieffer, G., Taylor, M., Nagpal, D., Khalid, A. (2014). RE-thinking Energy: Towards a new power system. Abu Dhabi, UAE: International Renewable Energy Agency (IRENA).

Fouquet, D., Johansson, T.B. (2008). European renewable energy policy at crossroads: Focus on electricity support mechanisms. Energy Policy 36(9); pp. 4079--4092.

Frontier Economics. (2014). Technologieoffene Ausschreibungen für Erneuerbare Energien Studie für EFET Deutschland. London, Frontier Economics Ltd. Available at: http://efetd.org/Cms Data/Contents/EFETDeutschlandDatabase/Folders/Documents/Verschiedenes/EF ET-Veroffentlichungen/ contents/QF3JSK3Z48MN9KDY/EFET-Deutschland-Studie-26-062014.pdf.

Gratwick, K. N., Eberhard, A. (2008). Demise of the standard model for power sector reform and the emergence of hybrid power markets. Energy Policy 36(10); pp. 3948-3960. 
GRENLEC. (2011). GRENLEC's renewable standard offer (Version 1.1). St. George's, Grenada. Available at: http://www.grenlec.com/Portals/0/StandardOffer/ Grenlec\%20Renewable\%20Standard\%20Offer.pdf.

Hansen, L., Lacy, V., Glick, D. (2013). A review of solar PV benefit \& cost studies. Boulder, CO: Rocky Mountain Institute, Electricity Innovation Lab (e-Lab).

Hauser, E., A. Weber, et al. (2014). Bewertung von Ausschreibungsverfahren als Finanzierungsmodell für Anlagen erneuerbarer Energienutzung Saarbrücken, Institut für ZukunftsEnergieSysteme (IZES gGmbH). Available at: http://www.beeev.de/Publikationen/IZES2014-05-20BEE EE-Ausschreibungen Endbericht.pdf.

Huber, C., Faber, T., Haas, R., Resch, G., Green, J., Ölz, S., et al. (2004). Green-X: Deriving optimal promotion strategies for increasing the share of RES-E in a dynamic European electricity market. Vienna, Austria: Vienna University of Technology Energy Economics Group.

Hurlbut D. (2008). State slean energy practices: Renewable portfolio standards. TP-67043512. Golden, CO: National Renewable Energy Laboratory.

International Energy Agency. (2014). Energy technology perspectives 2014: Harnessing electricity's potential. Paris, France.

Jacobs, D. (2012). Renewable Energy Policy Convergence in the EU - The evolution of feedin tariffs in Germany, Spain and France. Farnham, Ashgate Publishing.

Jacobs, D. (2015). Designing financing mechanisms for electricity from renewable energy sources - the role of the European Commission as an agenda shaper Building the Agenda Energy Policy Making in the EU. J. Tosun, S. Schmitt and K. Schulze. London, Springer .

Jacobs, D., Sovacool, B. (2012). Feed-in tariffs and other support mechanisms for solar PV promotion: case studies from Germany, Spain, Singapore and the US. Comprehensive Renewable Energy. W. v. Sark and L. Kazmerski. New York, Elsevier. 1: 73-109.

Jacobsson, S., A. Bergek, et al. (2009). EU renewable energy support policy: Faith or facts? . Energy Policy 37(6); pp. 2143-2146.

Joskow, P. L. (2008). Lessons Learned from Electricity Market Liberalization. The Energy Journal (Special Issue); pp. 9-42.

Kost, C., Mayer, J. N., Thomsen, J., Hartmann, N., Senkpiel, C., Philipps, S., et al. (2013). Levelized cost of electricity renewable energy technologies study. Freiburg, Germany: Fraunhofer Institute for Solar Energy Systems ISE.

Krasko V. A., Doris, E. (2012). Strategic sequencing for state distributed PV policies: A quantitative analysis of policy impacts and interactions. NREL/TP-7A30-56428. Golden, CO: National Renewable Energy Laboratory.

Kreycik C. E., Couture T. D., Cory K., (2011). Procurement options for new renewable electricity supply. NREL/TP-6A20-52983. Golden, CO: National Renewable Energy Laboratory. 
Lauber, V. (2004). REFIT and RPS: Options for a harmonised community framework. Energy Policy 32(12); pp. 1405-1414.

Lucas, H., Ferroukhi, R., Hawila, D. (2013). Renewable energy auctions in developing countries. Abu Dhabi, UAE: International Renewable Energy Agency (IRENA).

Maurer, L. T. A., Barroso, L. A. (2011). Electricity auctions: An overview of efficient practices. Washington, DC: World Bank, Energy Sector Management Assistance Program.

Miller, M., Bird, L., Cochran, J., Milligan, M., Bazilian, M., Denny, E., et al. (2013). RES-ENEXT: Next generation of RES-E policy instruments. Paris, France: International Energy Agency Renewable Energy Technology Deployment (IEA-RETD).

Million Rooftop PVs. (2014). Solar PV generation wholesale rates. Available at: http://mrpv.org.tw/about.php?id=8.

Ming-Zhi Gao, A. (2014). A more sustainable way to promote PV: Transformations from FIT to FIT/FIT tendering schemes in Taiwan and France. Legal issues of renewable energy in the Asia Region: Recent development in a post-Fukushima and post-Kyoto Protocol rra. The Netherlands, Kluwer Law International: 38.

Ming-Zhi Gao, Anton. (2014b). Personal communication (August 18 2014), Anton Ming-Zhi Gao Assistant Professor, The Institute of Law for Science and Technology (ILST), National Tsing Hua University, Taiwan.

Ministry of Energy. (2010). Feed-in-tariffs policy on wind, biomass, small-hydro, geothermal, biogas and solar resource generated electricity (1st Revision). Nairobi, Kenya.

Ministry of Environment and Energy. (2014). Net-metering program for grid-tied renewable energy generation in Seychelles. Victoria, Seychelles: Seychelles Ministry of Environment and Energy.

Nimmons, J. (2009). Comments of Recurrent Energy on Administrative Law Judge's Ruling Regarding Pricing Approaches \& Structures for a Feed-in Tariff (Rulemaking 08-08-009). San Francisco, CA: California Public Utilities Commission.

Photovoltaique Info. (2014). Procédures d'appels d'offres. Available at: http://www.photovoltaique.info/Procedures-d-appels-d-offres.html.

Photovoltaique Info. (2014b) Aujourd'hui : arrêté du 4 mars 2011. Available at: http://www.photovoltaique.info/Aujourd-hui-arrete-du-4-mars-2011.

Rader, N., Hempling, S. (2001). The renewables portfolio standard: A practical guide. Washington, DC: National Association of Regulatory Utility Commissioners.

Rader, N., Norgaard, R. (1996). Efficiency and sustainability in restructured electric utility markets: The renewables portfolio standard. The Electricity Journal (9); pp. 37-49.

Ray, S., J. Munksgaard, et al. (2010). Wind energy and electricity prices: Exploring the 'merit order effect'. Brussels, Belgium, European Wind Energy Association.

REN21. (2014). Renewables 2014 global status report. Paris, France: REN21 Secretariat. 
Rickerson, W., Couture, T., Barbose, G., Jacobs, D., Parkinson, G., Chessin, E., Belden, A. (2014). Residential prosumers: Drivers and policy options (RE-PROSUMERS). Paris, France: International Energy Agencey Renewable Energy Technology Deployment (IEA-RETD).

Rickerson, W., Uppal, J., Glassmire, J., Lilienthal, P., Sanders, E., Colson, C., Couture, T., et al. (2012). Renewable energies for remote areas and islands (REMOTE). Paris, France: International Energy Agency Renewable Energy Technology Deployment (IEA-RETD).

Ringel, M. (2006). Fostering the use of renewable energies in the European Union: The race between feed-in tariffs and green certificates. Renewable Energy (31:1); pp. 1-7.

Sáenz de Miera, G., P. Del Río González, et al. (2008). Analysing the impact of renewable electricity support schemes on power prices: The case of wind electricity in Spain. Energy Policy 36(9); pp. 3345-3359.

Sensfuß, F., Ragwitz, M. (2007). Analysis of the price effect of renewable electricity generation on spot market prices. Karlsruhe, Germany, Fraunhofer Institut System- und Innovationsforschung.

Sherry, P. (2013). UK contracts for difference: Risks and opportunities. London, UK: Baringa Partners.

Sovacool, B. (2011). The policy challenges of tradable credits: A critical review of eight markets. Energy Policy (39:2); pp. 575-585.

Tasmanian Government. (2013). Feed-in tariffs: Transition to full retail competition - Issues paper. Hobart, Tasmania.

Trabish, H. (2014, January 13). Solar's faceoff: Feed in tariff versus net energy metering. TheEnergyCollective.com. Retrieved from http://theenergycollective.com/hermantrabish/326831/solar-s-faceoff-feed-tariff-versus-netenergy-metering.

UK Government. (2014). Contract for Difference: Draft Allocation Framework. London, UK Government, Department of Energy and Climate Change.

Wamukonya, N. (2003). Power sector reform in developing countries: Mismatched agendas. Energy Policy (31); pp. 1273-1289.

Wirth, H. (2014). Aktuelle Fakten zur Photovoltaik in Deutschland. Freiburg, Germany: Fraunhofer ISE.

Wiser, R., Pickle, S., Goldman, C. (1996). California renewable energy policy and implementation issues. LBNL-39247. Berkeley, CA: Lawrence Berkeley National Laboratory.

Yueh-Hsun Tsai. (2014). Personal communication (September 9 2014), Professor Yueh-Hsun Tsai, Associate Professor of Law at National Yunlin University of Science and Technology, Taiwan. 